ELIZABETA IGREC

Gradski muzej Varaždin

elizabeta.igrec@gmv.hr
Primljeno: 01. 02. 2019.

Prihvaćeno: 06 11. 2019.

DOI: 10.21857/yk3jwhr7p9

DANIELA RATKAJEC

Hrvatski restauratorski zavod

dratkajec@h-r-z.hr

\title{
IZABRANI PRIMJERI GRAFIKA IZ ZBIRKI GALERIJE STARIH I NOVIH MAJSTORA GRADSKOG MUZEJA VARAŽDIN
}

Članak je podijeljen u dva dijela u kojem prvi iznosi kratak pregled grafičke umjetnosti, zastupljenih autora (rezača, crtača, tiskara) i grafičkih listova iz Zbirke slika, skulptura, grafika i crteža. Temelji se na suradnji Gradskog muzeja Varaždin i Hrvatskog restauratorskog zavoda koja pridonosi sustavnim restauriranjem očuvanju grafičke umjetničke baštine. U drugom dijelu opisan je postupak konzervatorsko-restauratorskog zahvata na dva japanska drvoreza iz 18. stoljeća s kratkim opisima grafičkih listova i biografskim osvrtom na izuzetno značajne autore-rezače.

\section{DIO}

Zbirka slika, skulptura, grafika i crteža Galerije starih i novih majstora Gradskog muzeja Varaždin broji oko 2400 vrijednih grafičkih listova i trideset i pet grafičkih mapa. Zbirka je nastajala i popunjavala se paralelno s razvojem Gradskog muzeja Varaždin od osnutka 1925. godine pa sve do današnjih dana. Najveći dio grafičkih listova pristigao je u muzej u razdoblju od 1943. godine do 1946. godine u vrijeme i nakon Drugog svjetskog rata. Prema podacima iz starih inventarnih knjiga kao i sačuvane opće dokumentacije muzeja, veći broj grafičkih listova do- 
nirali su njihovi vlasnici, jedan dio pristigao je iz javnih ustanova grada i županije dok je manji broj bio otkupljen ili pak konfisciran. Zahvaljujući ondašnjem ravnatelju muzeja Krešimiru Filiću, njegovim suradnicima i Muzealnom društvu koje je djelovalo vrlo aktivno i pozitivno, brojni privatni vlasnici umjetnine su darovali muzeju, upravo s nakanom da se sačuvaju za budućnost te ostanu svjedočanstvom njihovih kulturnih dosega. U posebnu inventarnu knjigu upisivale su se samo grafike, što je dokaz da je od samih početaka muzeja brojnost grafičkih listova bila izuzetno velika te potreba da se njihova inventarizacija vodi zasebno. Grafički listovi koji su danas sastavni dio zbirke nekada su bili vlasništvo uglednih obitelji iz Varaždina i okolice, a neke od njih su Leitner, Bombelles, Drašković, Pongratz, Jaccomini i dr. za koje slovi da su bili veliki ljubitelji i štovatelji umjetnosti. Spomenute obitelji grafike su kupovale i donosile u svoje domove s brojnih putovanja Europom, kako bi krasile zidove, ali i statusno uzdizale vlasnike profinjena ukusa. One pak koje su krasile zidove javnih ustanova bile su političkog karaktera, prije svega povijesne, ali i umjetničke vrijednosti. Drugi veći niz grafičkih listova u muzej pristiže u drugoj polovici 20. stoljeća, 70-ih i 80-ih godina, posebice kroz grafičke mape suvremenih hrvatskih likovnih umjetnika.

Grafički listovi iz fundusa galerije nastali su, odnosno otisnuti su u vremenskom periodu od početka 17. stoljeća do danas. Grafike starije datacije iz perioda 17., 18. i početka 19. stoljeća čine „najčvršću jezgru Zbirke“1 jer prezentiraju grafike proizašle iz najjačih grafičkih radionica europskih središta umjetnosti kao što su Amsterdam, Beč, Pariz, Rim i Venecija. Širenje grafičke umjetnosti u Europi toga vremena doprla je i do naših krajeva, a potvrda tomu su signirani grafički listovi poznatih inventora/slikara i crtača, rezača, tiskara i izdavača. Brojni listovi su grafički otisci gravirani prema slikama drugih slikara, što je bilo vrlo rasprostranjeno. Takve grafike često se nazivaju interpretativne grafičke slike koje su prije svega imale funkciju slikovne informacije u službi edukacije. Mnogi grafičari uz kopije tuđih slika rade i vlastite skice prema kojima režu ploče, a takvih primjera u zbirci ima mnogo. Zastupljene su gotovo sve grafičke tehnike kao što su drvorez, bakrorez, suha igla, bakropis, punktiranje, mezzo- i akvatinta, litografija kao i brojne druge kombinirane grafičke tehnike. Uz grafičke tehnike i teme su raznovrsne, religijske, mitološke i alegorijske, pejsaži, povijesne, žanr-scene, vedute, mrtve prirode, portreti itd.

Grafička umjetnost postupnim razvojem brojnih tehničkih mogućnosti graviranja uvijek je oduševljavala crtaćim vještinama, linijama i linijskim sistemima crteža s velikim tonskim rasponima. Takve kvalitetne grafičke slike nastajale su

1 Ljepote grafičke umjetnosti, Mirjana Dučakijević, katalog izložbe, Gradski muzej Varaždin, 2011., str. 5 
zahvaljujući vrlo organiziranim grafičkim radionicama gdje se izučavao grafički zanat graviranja i otiskivanja. Umnožavanje grafičkih listova donijelo je slavu ovoj izuzetnoj umjetničkoj vještini, jer je izrada postala jeftinija te je time postala dostupna širim slojevima kupaca.

Diljem Europe postupno se formiralo tržište grafičkih listova, njihova kupnja bila je sve jednostavnija i dostupnija, tako se u Njemačkoj u drugoj polovini 16. stoljeća počinju otvarati specijalizirane radnje tzv. Kunstkammeri u kojima su se prodavale umjetnine i grafički listovi. U Antwerpenu su se grafike prodavale pred samom burzom, a u Veneciji je za prodaju umjetnina bio određen prostor na Trgu sv. Marka, ispred crkve San Rocco i na mostu Rialto. U 17. stoljeću u Rimu grafički listovi se prodaju u Panteonu ili pod zidovima crkve Santa Maria di Constantinopoli, kasnije pokraj crkve San Giovanni Decolatto. U Parizu je, osim u manjim trgovinama, organizirana prodaja grafika na umjetničkim salonima. „S vremenom se u nabavu umjetnina uključuje uz viši i srednji stalež stanovništva. Potražnja za jeftinom grafičkom umjetninom bivala je sve veća. Ovisno o mogućnostima kupovali su je sitni građani pa i seljaci. Sve je to neminovno dovelo do hiperprodukcije i posljedično do razvijanja novih grafičkih tehnika i još povoljnijih cijena grafičkih listova. Tako iz zapisa jednog nizozemskog kroničara doznajemo da je u Antwerpenu 1560. godine bilo 300 slikara i grafičara naspram svega 169 pekara i 78 mesara." ${ }^{2}$

Najstariji grafički listovi datiraju s početka 17. stoljeća te pripadaju nizozemskim i flamanskim autorima koji ujedno predstavljaju i ponajbolja grafička ostvarenja zbirke: Cornelis Galleus, Cornelis Visscher, Nicolaes de Bruyn, Frans de Bakker, Johannes Londerseel, Jan Punt, Valk Gérar, Anton Mauve i dr.. Cornelis Galleus (1576. - 1607.) nezaobilazno je ime nizozemske grafike, kao grafičar afirmirao se prvo u Italiji, radeći grafike prema slikama Rafaela, Carraccia, Tiziana i Renija. Po povratku u rodni Antwerpen postao je član majstorskog ceha gravera i utemeljitelj kaligrafskog instituta. Zajedno s bratom Theodorom, bio je prvi grafičar koji je umnožavao grafike prema predlošcima P. P. Rubensa. U Zbirci se čuva njegov bakropis nastao prema predlošku slike P. P. Rubensa Ecce Homo (sl. 1). Cornelis Visscher (1619.? - 1662.) jedan je od najznačajnijih predstavnika nizozemskog bakropisa. Bio je izuzetan crtač, većinu grafika izvodio je prema vlastitim skicama, a njegove grafike odlikuju se finim nijansiranjem i mekoćom modeliranja. Bio je učenik Rembrandta van Rijna. U zbirci se nalaze dva njegova grafička otiska, bakropisi s prikazima pejsaža: Krajolik s ljudima (sl. 2) i Kralj David i Jonathan. Nicolaes de Bruyn (1571. - 1656.) isticao se kao jedan

2 Ljepote grafičke umjetnosti, Mirjana Dučakijević, katalog izložbe, Gradski muzej Varaždin, 2011., str. 6. 
ELIZABETA IGREC, DANIELA RATKAJEC: Izabrani primjeri grafika iz Zbirki galerije starih i novih majstora ..
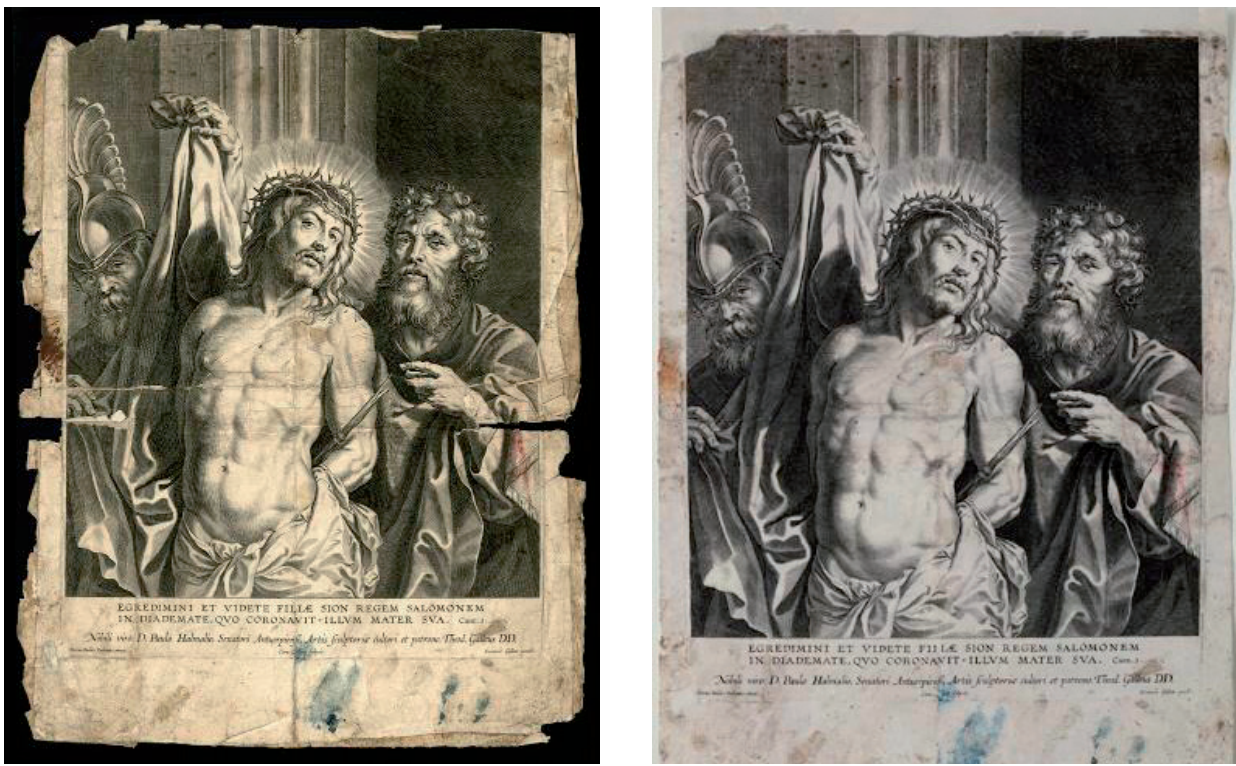

Slika 1. Grafički list prije i poslije restauratorskog zahvata, Ecce Homo Prva polovina 17. stoljeća. Slikar: Peter Paul Rubens, rezač: Cornelis Galleus, izdavač: Ioannes Galleus, bakropis; ploča: $37 \times 28 \mathrm{~cm}$, papir: $42 \times 33 \mathrm{~cm}^{3}$

od značajnijih flamanskih grafičara, koji je zanat izučio kod strica Abrahama de Bruyna, a stil razvio u smjeru svojeg grafičkog uzora Lukasa van Leydena. Gravira prema vlastitim crtaćim predlošcima, bogate i detaljima zahtjevne kompozicije, što se može primijetiti i na grafici iz fundusa Seoska svečanost u Midellburgu (sl. 3). Gérard Valek (1626. - 1720.) još je jedan nizozemski autor koji nesumnjivo predstavlja visoke dosege nizozemskog grafičkog umijeća. Za bakropis Kralj $i$ njegova pratnja (sl. 4) on je rezač ploče, a Nicolaes de Bruyn crtač. Svoje majstorstvo dokazuje mekoćom modeliranja, finog nijansiranja, kroz svijetlo-tamne kontraste harmonično izmjenjuje osvjetljenje dajući krajolik u njegovoj punoj prirodnosti. Njegova grafička ostvarenja uglavnom se temelje na predlošcima

\footnotetext{
Dolje tekst „ENGREDIMINI ET VIDETE FILLAE SION REGEM SALOMONEM/ IN DIADEMANTE, QVO CORONAVIT ILLVM MATER SVA. Cant.3."

„Nobili viro D. Paulo Halmalio, Senatori Antuerpienis, Artis sculptoriæ cultori et patrono, Theod. Galleus D.D.”, sign. d.I. „Petrus Paulus Rubenius pinxit.“; d. sredina „Corn. Galleus Sculpsit.”; d.d. „Ioannes Galleus excudit.", GMV 62167. Restaurirano: HRZ, Odsjek za papir i kožu, 2011.
} 
drugih slikara (Peter Lely, Gerard de Lairrese). U Amsterdamu je radio u suradnji sa svojim sinom Leonardom Valckom i Peterom Schenkom starijim. Bio je izuzetno cijenjen kao vrstan kartograf.

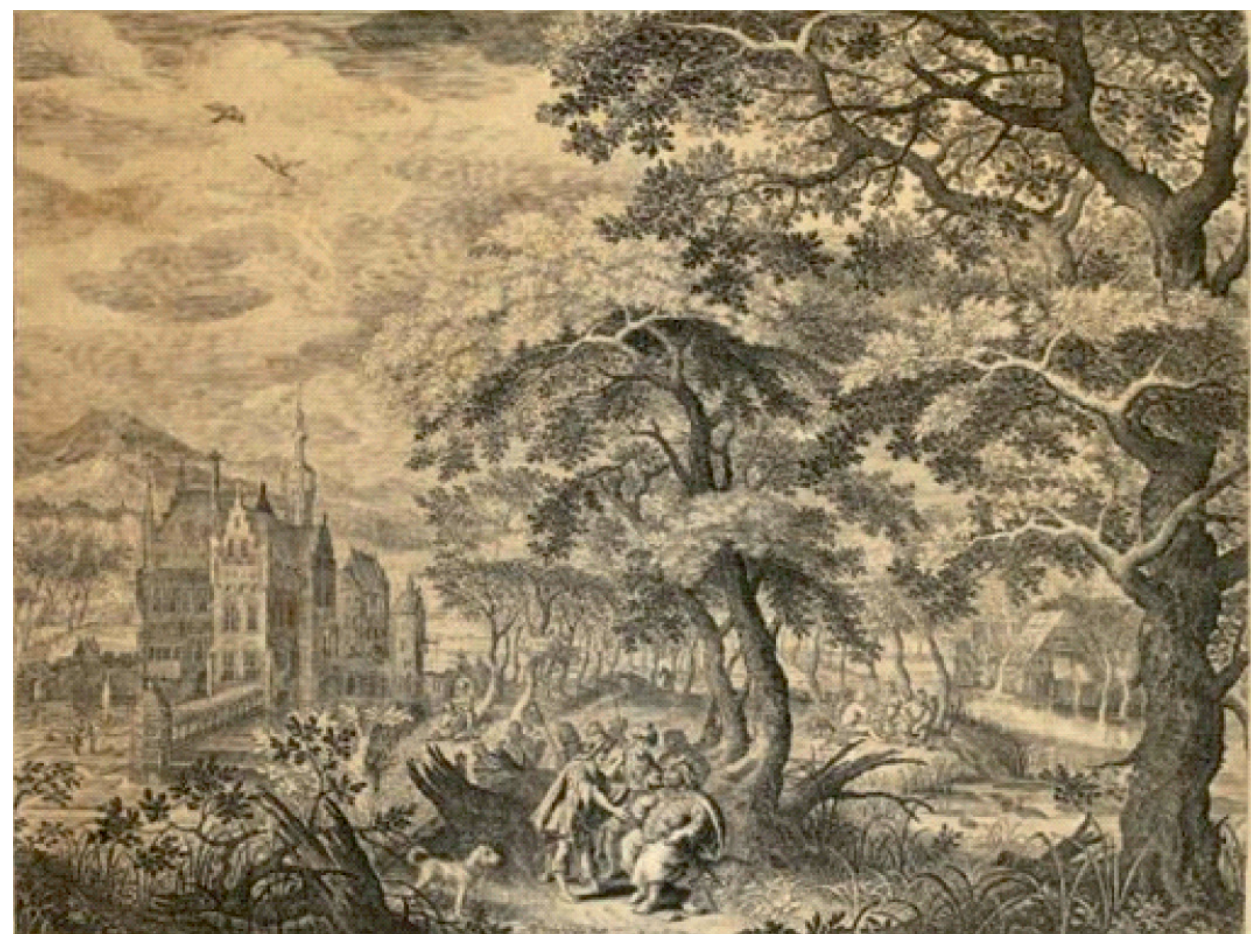

Slika 2. Krajolik s ljudima, 17. stoljeće. Rezač: Joan Londersel, izdavač: Chornelis Visscher bakrorez i bakropis; papir obrezan $37,5 \times 49 \mathrm{~cm}^{4}$

4 Sign. d. sredina „Hen. Daenelsen Inven“; „Joan a Londersel Schulp“; „Visscher excudit“, GMV62049, restaurirano: HRZ, Odsjek za papir i kožu, 2010. 


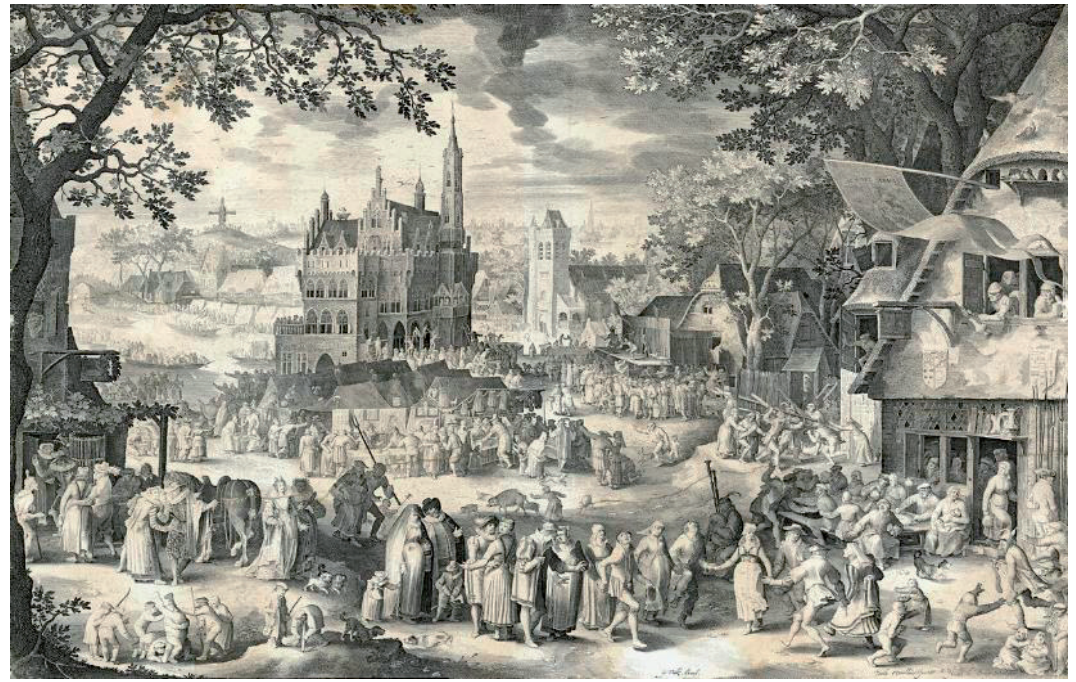

Slika 3. Seoska svečanost u Middelburgu, 17. stoljeće. Izumitelj: David Vinckboons, rezač: Nicolaes de Bruyn, izdavač: Valck Gerard, bakrorez; papir obrezani 43,5 x 69,7 cm 5

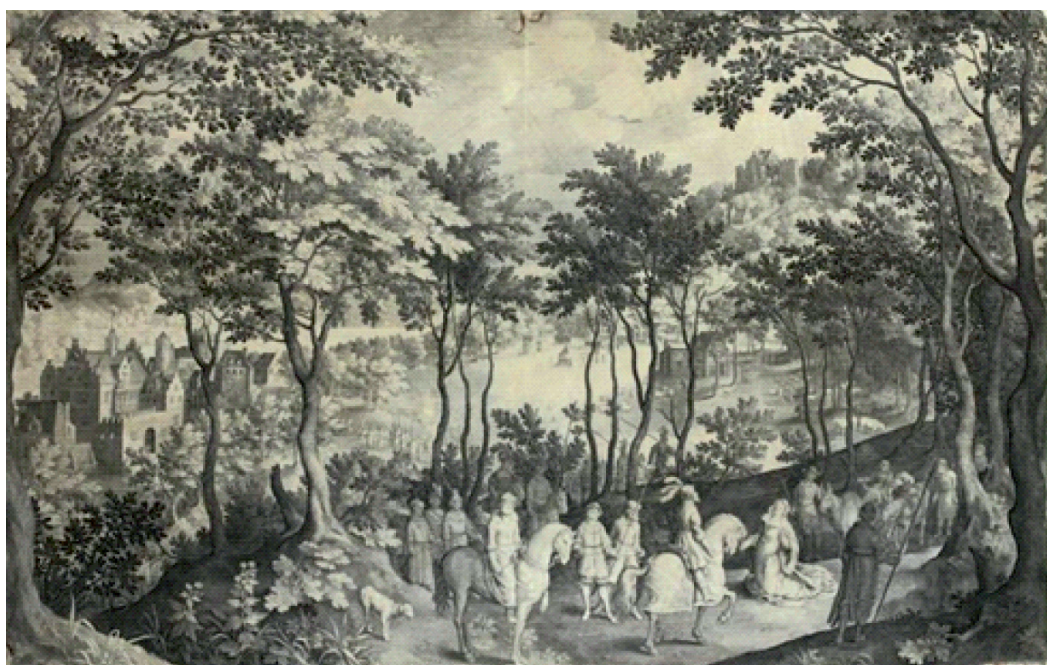

Slika 4. Kralj i njegova pratnja, 1608. Crtač: Nicola de Brijn, rezač: Gerard Valck bakropis i bakrorez; papir obrezan $42 \times 66,5 \mathrm{~cm}^{6}$

5 Sign. d. sredina „G. Valck excud.“; d.d. „Davide Vinckboons invent.“; Nicola de Bruyn Sculptor“ GMV 58203.

6 Sign. d. s. „1608 N. de Brijn“; d.d. „G. Valck Excud.“, GMV 62051. Restaurirano: HRZ, Odsjek za papir i kožu, 2010. 
Među grafičarima ističe se i velik broj francuskih majstora: Thiboult Benoit, Joseph Vernet, Edmond Jeaurat, François Philipe Charpentier, Renè Gaillard, Nicolas-Henri Tardieu, Anne Philiberte Coulet, Philippe de Champaigne, Claude Lorrain, Jacques-Philippe Le Bas, François Denis Née, Gustave Marie Greux.

Nicolas-Henri Tardieu (1674. - 1749.) i Renè Gaillard (1719. - 1790.) oboje priznati francuski grafičari poznati po grafikama rađenim prema predlošcima proslavljenih slikarskih majstora rokokoa. Slavu vrsnih grafičara stekli su upravo neprikosnovenim reprodukcijama koje su u crno-bijeloj grafici, vrlo često kolorirali u tehnici akvarela i tako dočaravali svu raskoš, lepršavost i kolorističko bogatstvo rokokoa sa slika suvremenika. Nicolas-Henri Tardieu proslavio se reproduciranjem djela Antoinea Wateaua. Bio je i dvorski grafičar kralja Luja XV. Druga supruga Marie Anne Horthemels bila je i sama grafičarka iz ugledne i cijenjene grafičke obitelji te su zajedno stvorili brojna grafička ostvarenja koja su zajednički publicirali. U zbirci se nalazi grafika Igra, izrađena prema slici slikara Nicolasa Lancreta. Renè Gaillard najcjenjeniji je po reprodukcijama prema slikaru Françoisu Boucheru, čije četiri grafike Skrivanje (sl. 5), Par, Osamljena ovčica, Nagrađeni pastiri u tehnici bakroreza i bakropisa, krase zbirku i dokazuju njegovo majstorstvo. Anne Philiberte Coulet (1736. - 1800.) jedna je od rijetkih grafi-

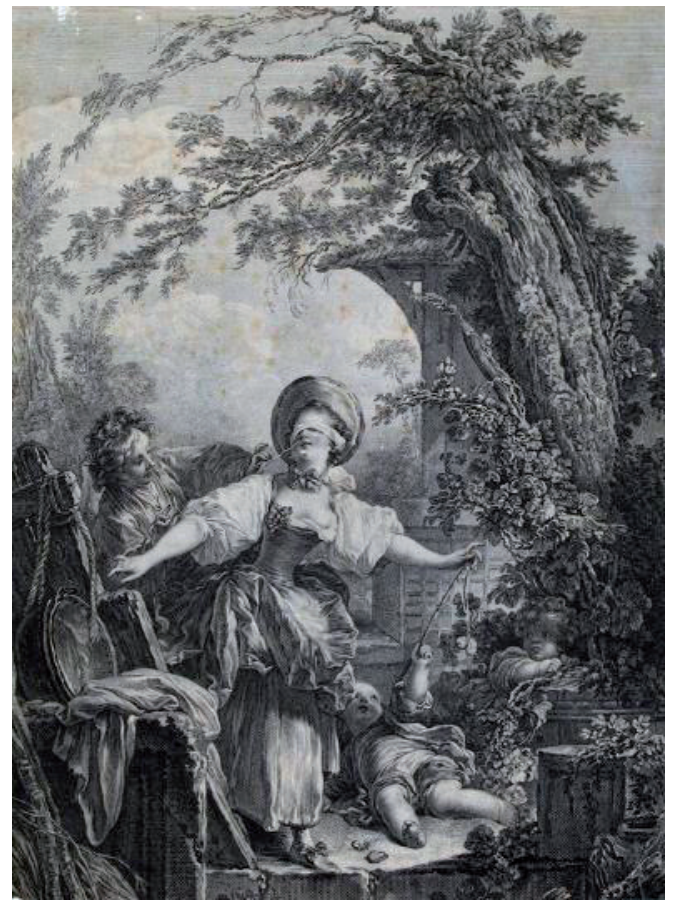

čarki 18. stoljeća, uglavnom je radila u tehnici bakroreza, a najpoznatija su joj djela rađena prema slikama C. J. Verneta s prizorima ribara, od kojih je jedan bakrorez pod nazivom Napuljski ribari (sl. 6) našao mjesto u zbirci. Njezino majstorstvo vidljivo je $u$ tonski suptilnoj i vrlo minucioznoj razradi detalja. François-Philippe Charpentier (1734. - 1817.), osim što je bio vrsni rezač, dao je velik doprinos grafičkom zanatu kao izumitelj prvih mehaničkih i kemijskih procesa u tehnici akvatinte. Grafika Udari vjetra (sl. 7) izrađena je prema istoimenom djelu suvremenika slikara Claudea Josepha Verneta.

Slika 5. Skrivanje, 18. stoljeće. Slikar: François Boucher, rezač: Renè Gaillard ${ }^{7}$

Bakrorez i bakropis; papir obrezan 39 × 28,5 cm, GMV 62378. 


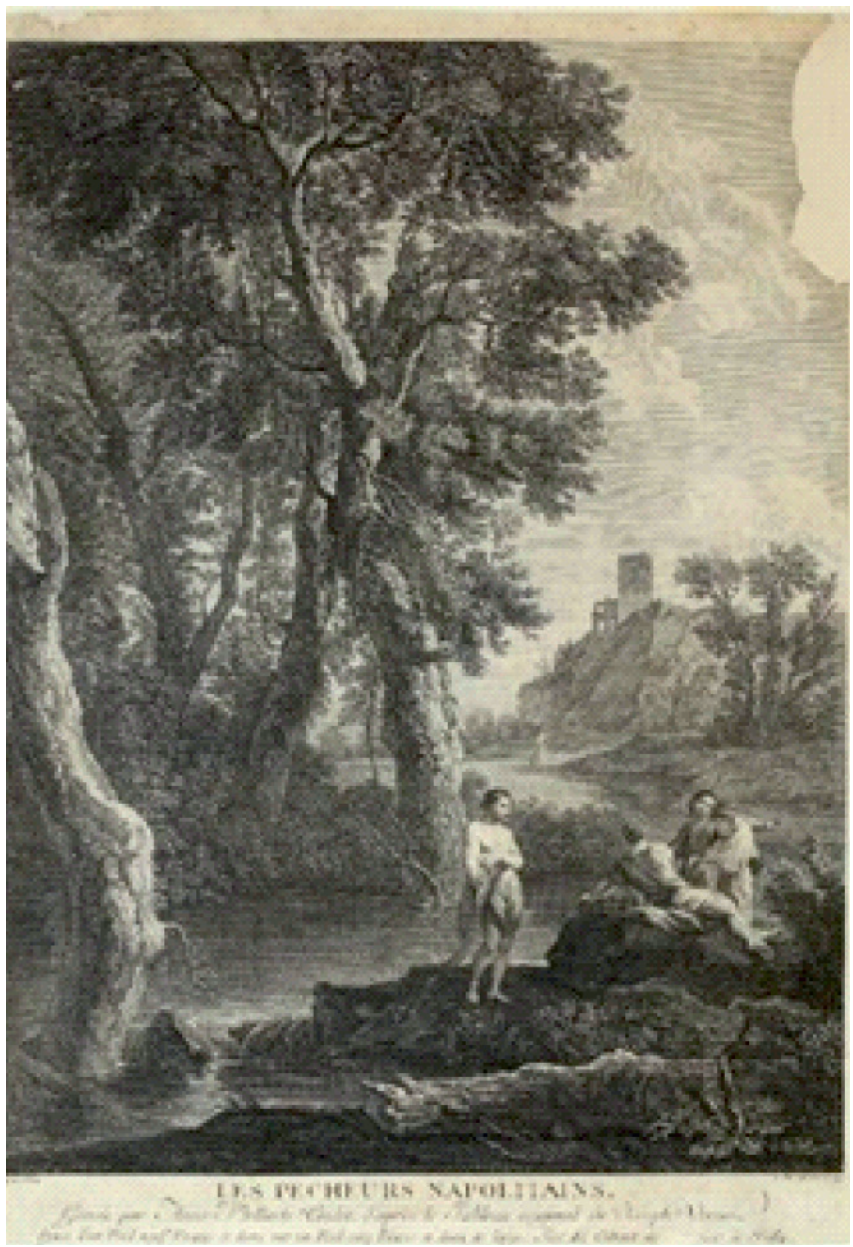

Slika 6. Napuljski ribari, 18. stoljeće. Slikar: Joseph Vernet, rezačica: Anne Philberte Coulet, bakrorez; otisak 44,5 x 33,3 cm, papir obrezani $48,5 \times 34,7 \mathrm{~cm}^{8}$

8 Sign. d. I. „J. Vernet Pinx.“; d.d. „ A. Ph.Coulet Sculp.“ Dolje naslov: „, LES PECHEURS NAPOLITAINS./ Gravés par Anne Philberte Coulet, d'après le Tableau original de Joseph Vernet,/haut d'un pied neuf Pouces et demi sur un Pied cinq Pouces et demi de large. Tiré du Cabinet de (nečitko) ...sieur de Billy.", GMV 62045. Restaurirano: HRZ, Odsjek za papir i kožu, 2010. 


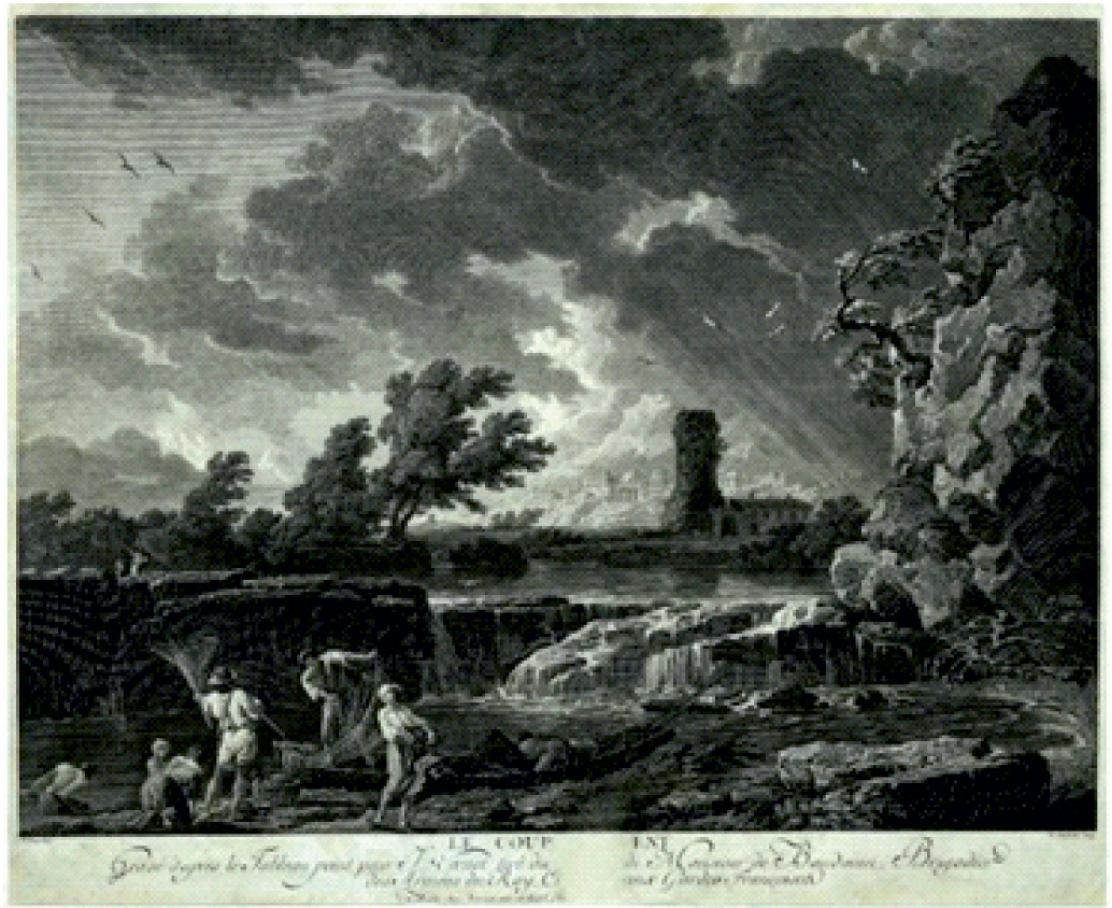

Slika 7. Udari vjetra, 19. stoljeće. Slikar: Claude Joseph Vernet, rezač: François-Philippe Charpentier. Bakrorez i jetkanje; papir cjelina: 60 x 78,5 cm; otisak: $44,5 \times 54 \mathrm{~cm}^{9}$

Duga i bogata grafička povijest Njemačke pridonjela je brojnim predstavnicima u zbirci. Vrlo vrijedan primjerak je grafička mapa Trijumf cara Maksimilijana I. Habsburškog (sl. 8), koja broji 137 vrijednih grafičkih listova u tehnici drvoreza. Ta mapa treći je pretisak prema originalnim pločama, tiskana u Beču na prijelazu iz 1883. godine u 1884. godinu od izdavača Adolfa Holzhausena. Autori originalnih ploča su Hans Burgkmair, Albrecht Altdorfer, Leonard Beck, Hans Springinklee, Hans Schäufelein i Albrecht Dürer. U zbirci se nalaze i brojna djela Johanna Eliasa Ridingera, koji je izuzetno značajan po bakrorezima sa scenama iz lova kao i životinjskim motivima. U rodnome Ulmu izučio je slikarski zanat kod slikara Christana Rescha, a nastavio je svoj slikarski nauk kod poznatog slikara animalista koji ga oduševljava za scene sa životinjskim prikazima. Gotovo cijeli slikarski i grafički život posvetio je prikazu životinja i scenama iz lova od kojih je značajan broj od ukupno 25 grafičkih listova zastupljen u fundusu. Posebno zanimljiv je grafički

9 GMV 65307, restaurirano: HRZ, Odsjek za papir i kožu, 2016. 
list naslovljen Autoportret Johanna Eliasa Ridingera (sl. 9) gdje autor prikazuje sebe u šumi sa štafelajem i kistovima. Plemstvo je uvelike kupovalo grafike animalne tematike jer su lovačke sobe s izloženim takvim slikama bile uvriježene u dvorcima, palačama i kurijama posebno sjeverozapadne Hrvatske odakle su i ove grafike pristigle.

Od njemačkih i austrijskih autora u zbirci su zastupljena još brojna grafička imena: Johann Georg Bergmüller, Georg Friedrich Schmidt, Adam i Andreas Schmutzer, Elias Wiedemann, Valentin Fischer, Josef Kriehuber, Clemens Kohl, Johann Friedrich Jügel, Franz Wolf, Friedrich Gauermann, Eilers Gustav, Fränkel Friedrich, Höfel Blasius, Kohl Clemens, Kaiser Aleksander, Raab Johann Leonhard, Unger William, Werner Fritz. Među mnoštvom grafičkih listova spomenutih autora, vrijedno je izdvojiti dimenzijama impozantnu grafiku austrijskog grafičara Gustava Adolfa Müllera (1694. - 1767.) Smrt Publija Decija Musa (sl. 10), rađenu prema slici P. P. Rubensa. Djelovao je u Beču i Nürnbergu, a od 1727. bio je profesor na Akademiji u Beču. Istaknuo se kao vrstan bakrorezac reproducirajući djela R. Carriera i P. P. Rubensa. Za potrebe izlaganja na izložbi Varaždin pod krunom Habsburgovaca u HRZ-u Odsjeku za papir i kožu restaurirano je oko 30 grafika njemačkih i austrijskih autora, vezanih za obitelj Habsburg s tematskim prikazima portreta, povijesnih događaja i bitaka. Valja spomenuti grafičke listove iz mape litografija koja slavi najvažnije trenutke vladavine Franje I. Habsburško-Lotarinškog, Hauptmomente aus dem Leben Sr Majestät Franz I. Kaisers von Oesterreich, apostol. Königs, litografa Franza Wolfa prema akvarelima slikara Johanna Nepomuka Hoeclhea. U Gradskom muzeju Varaždin čuvaju se ukupno 24 lista iz te serije, tiskane u tri edicije, u Beču između 1830. i 1835. godine. ${ }^{10}$

10 Varaždin pod krunom Habsburgovaca, katalog izložbe, Varaždin, 2015.; str. 69 


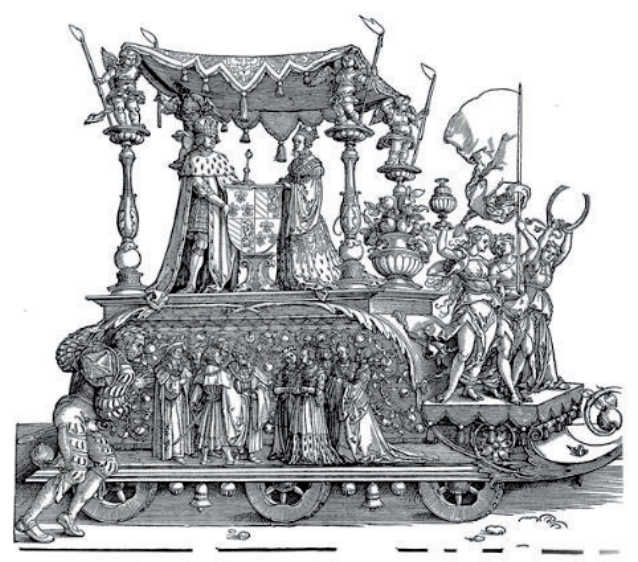

Slika 8. Trijumf cara Maksimilijana I. Habsburškog (List 90) - Povorka kola tisak i izdavač Adolf Holzhausen, K.K. Hof „Buchdrucker“, Beč, 1883.-1884. ${ }^{11}$

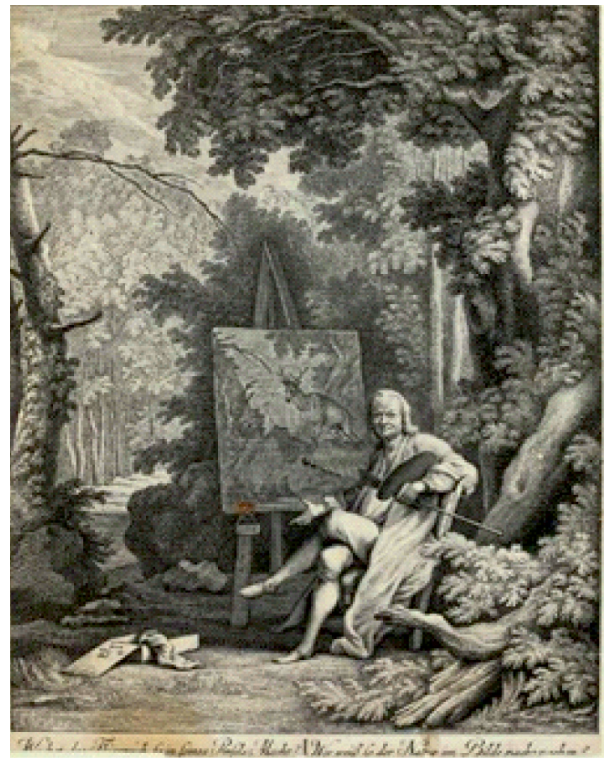

Slika 9. Autoportret slikara i bakrorezca Johanna Eliasa Ridingera, 18. Stoljeće. Slikar i rezač: Johann Elias Ridinger, bakrorez; otisak 28,4 x 22,8 cm, papir 29,4 x $23 \mathrm{~cm}^{12}$

11 List br. 90 od 137 iz mape „Triumph des Kaisers Maximilian I.“ kao prilog u „Jahrbuch der kunsthistorischen Sammlungen des Allerhöchsten Kaiserhauses", vol. I., drvorez, papir 46,3 x 60 cm, oznaka g.d. „90 / Fehlt B.“, GMV 64430.

12 Dolje tekst: „... so in seines Pinsels Macht? Wer weiss so der Natur im Bilde nachzugehen?“, GMV GS grafika 518. Restaurirano: HRZ, Odsjek za papir i kožu, 2011. 


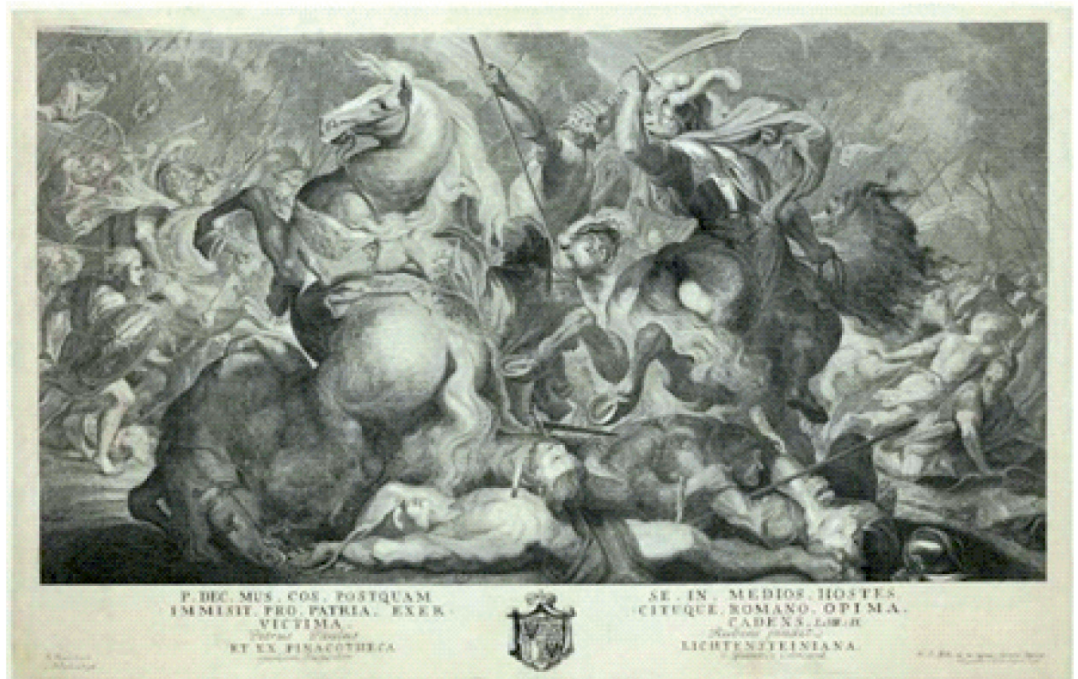

Slika 10. Smrt Publija Decija Musa, 1762. Rezač: Gustav Adolf Müller, slikar: P. P. Rubens, bakrorez; otisak $47 \times 85 \mathrm{~cm}$, papir $57 \times 90 \mathrm{~cm}^{13}$

Najznačajniji predstavnici talijanske grafike su grafičari koji su djelovali u 18. stoljeću i to na području Venecije. Tu se ističe Giovanni Battista Brustoloni (1712. - 1796.) suvremenik Canaletta, učenik velikog Josepha Wagnera. Radio je prema Canaletovim predlošcima. U svom radu najviše je kombinirao tehnike bakroreza i bakropisa, a svojim majstorstvom u svladavanju tehničkih i umjetničkih zadataka stekao je veliku slavu vrhunskog rezača - grafičara Venecije, i šire, još za života. Rezao je samo za najbolje venecijanske izdavače, poput glasovitog Ludovica Furlanetta, za kojeg je izradio seriju grafika Prospectum aedium, viarumque insigniorum urbis venetiarum posvećenu duždu Marcu Foscariniju. U zbirci čuvamo 11 grafičkih listova, od toga 6 listova pripada grafičkoj mapi iz serije Prospectum aedium, viarumque insigniorum urbis venetiarum (Venecija, Ludovico Furlanetto, 1763.) (sl. 11. i 12) i 5 listova iz grafičke mape Le Feste Ducali (Venecija, Ludovico Furlanetto, 1779.). Dvije kvalitetne grafike s prikazom grada Udina, Trg u Udinama i Pogled na palaču u Udinama (sl. 13) pripadaju još jednom predstavniku talijanske grafike Francescu Pedru (1740. - 1806.), gdje je rodne Udine prikazao prema crtežu Uldarica Mora. Učio je i djelovao u venecijanskim radionicama. Učenik čuvene venecijanske radionice Josepha Wagnera, Fabio Berardi (1728. - 1788.)

13 GMV 62143, restaurirano: HRZ, Odsjek za papir i kožu, 2016. 
zastupljen je u zbirci jednom grafikom Ljubav uz rijeku, s pridruženom pisanom mudrom izrekom (slične potpise mudrih izreka nalazimo na još dva primjera u zbirci koji se također odnose na talijanske grafičare). Vrijedna divljenja je i grafika Giuseppea Sforza Perinija (1748. - 1795.) nastala prema slikarskom djelu Guida Renija pod nazivom Arkanđeo Mihael (sl. 14). Tu su još grafičari Angelias Zaffonato, Luigi Rossini, Morghen Raffaello.

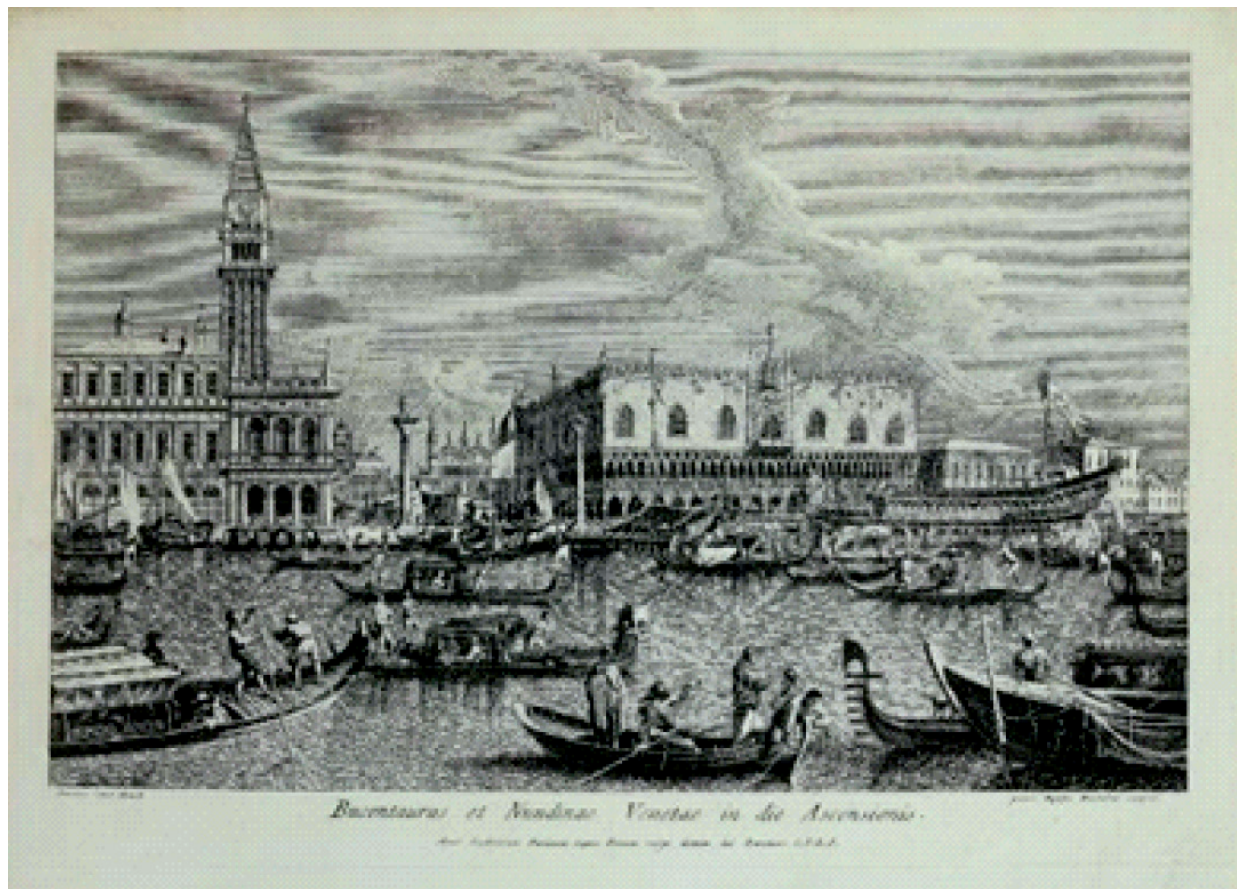

Slika 11. Povratak Bucintora na mol na Dan Uznesenja, 18. st. Slikar: Antonius Canal, rezač: Giovanni Battista Brustoloni, izdavač: Ludovicum Furlanetto. Bakrorez; ploča $32 \times 46 \mathrm{~cm}$, papir $35 \times 47,7 \mathrm{~cm}^{14}$

14 Sign. d. I. „Antonius Canal Pinxit“; d.d. „Joannes Baptista Brustoloni sculpsit.“ Dolje naslov u sredini: „Bucentaurus et Nundinae Venetae ni die Ascensionis./ „Apud Ludovicum Furlanetto supra Pontem vulgo dictum dei Baretteri C.P.E.S.“ Iz serije grafičke mape Prospectuum aedium, viarumque insigniorum urbis Venetiarum (Venecija: Ludovico Furlanetto, 1763.), GMV GS grafika 76. Restaurirano: HRZ, Odsjek za papir i kožu, 2011. 
ELIZABETA IGREC, DANIELA RATKAJEC: Izabrani primjeri grafika iz Zbirki galerije starih i novih majstora ...

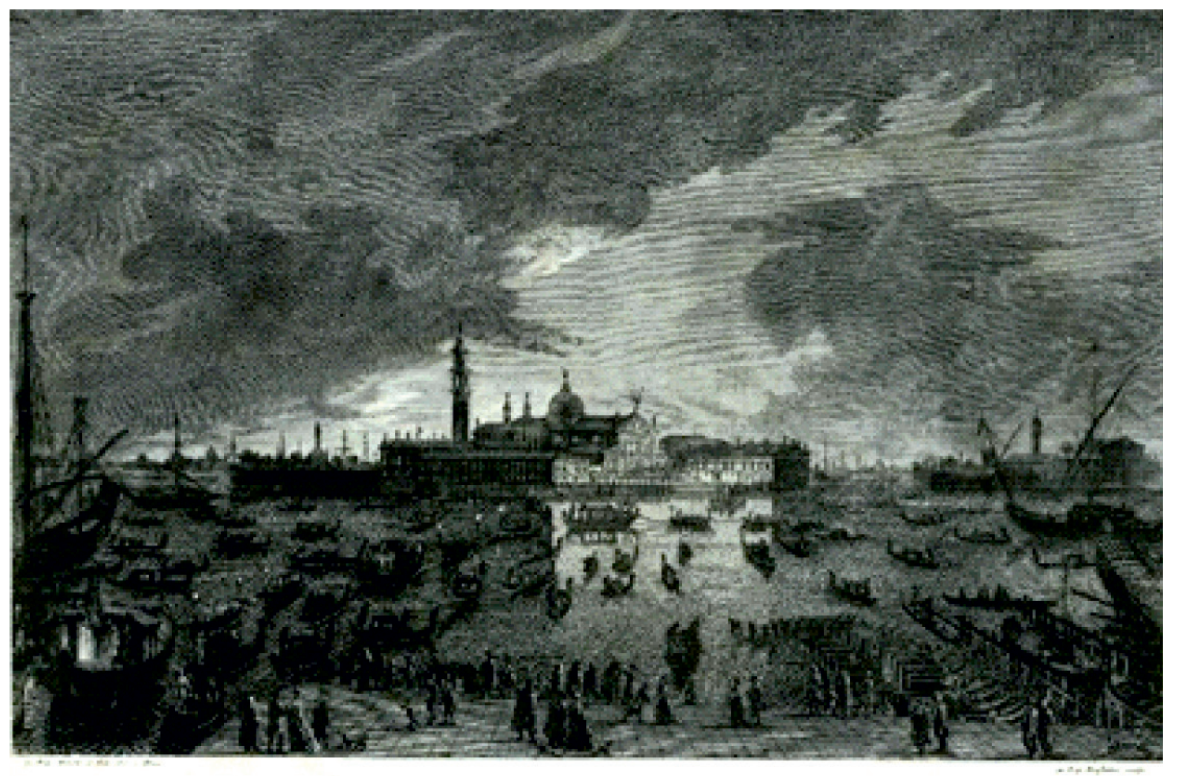

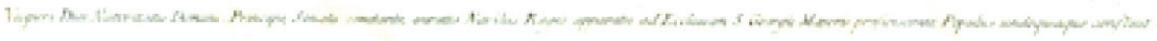

Slika 12. Na badnju večer dužd u pratnji senata i mnoštvo naroda kreće prema crkvi S. Giorgio Maggiore, 18. st. Slikari: Giovanni Battista Moretti i Filü del, rezač: Giovanni Battista Brustoloni. Bakrorez; ploča 32,5 x 46,2 cm; papir 34,9 x 47,2 cm ${ }^{15}$

15 sign. d.I. „Jo. Bap. Moretti et Filü del. e Pinx.“; d.d. „Jo. Bap. Brustoloni sculp.“ Dolje naslov: „Vesperi Diei Nativitatis Domini Principe, Senatu comitante auratis Navilüs Regio apparatu ad Ecclesiam S. Georgü Majoris proficiscente, Populus undequaque confluit.“/ „Apud Ludovicum Furlanetto supra Pontem vulgo dictum dei Baretteri C.P.E.S.“

Iz serije grafička mapa Prospectuum aedium, viarumque insigniorum urbis Venetiarum (Venecija: Ludovico Furlanetto, 1763.) GMV GS grafika 80. 


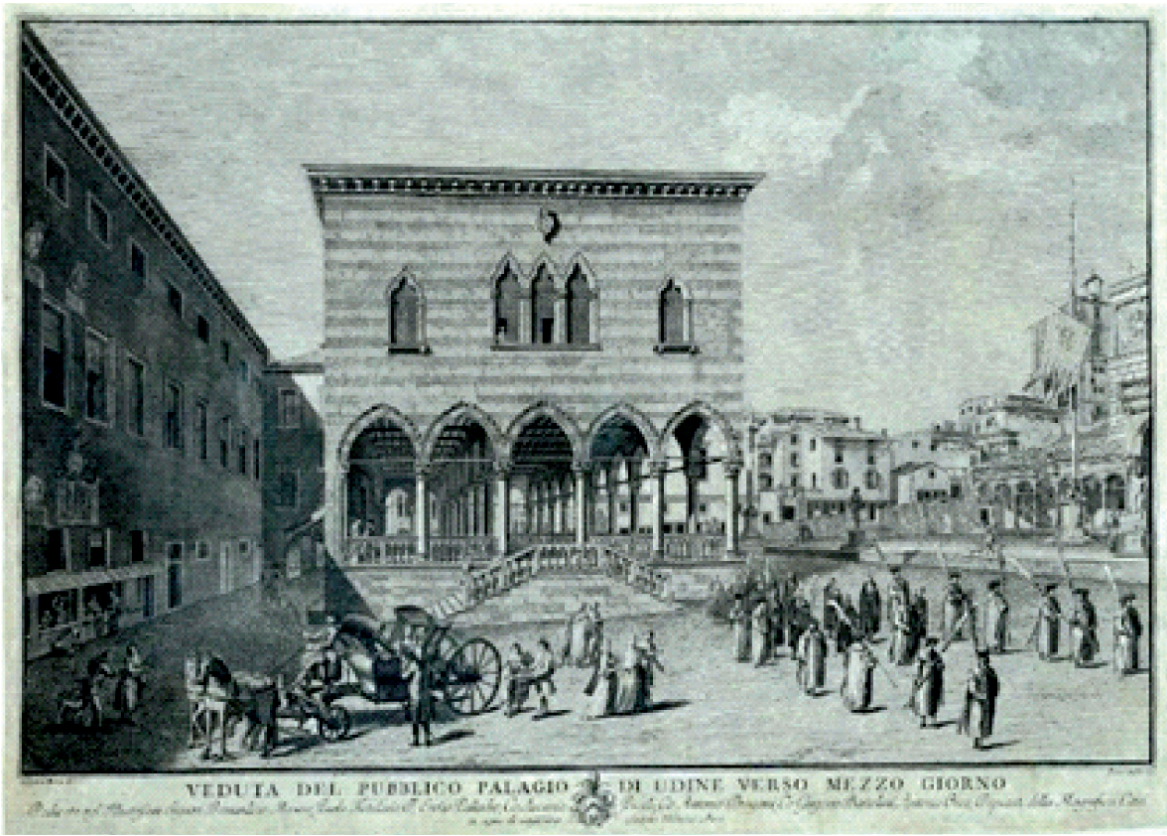

Slika 13. Pogled na palaču u Udinama, kraj 18. stoljeća, crtač: Uldarico Moro, rezač: Francesco del Pedro. Bakropis; otisak $42,5 \times 63 \mathrm{~cm}$, papir obrezani $46,5 \times 65 \mathrm{~cm}$, naljepljeno na platno ${ }^{16}$

16 sign. d.I. „Uldarico Moro del.“; d.d. „Franc. Pedro inc.“. U donjem dijelu tekst u čijoj je sredini grb: „VEDUTA DEL PUBBLICO PALAGIO=DI UDINE VERSO MEZZO GIORNO/Dedicata agl'Illustrissimi Signori Bernardino Masero, Paolo Fistulario D'., Enrico Palladio, Co: Ascanio=Picoli, Co: Antonio Dragoni, Co: Gregorio bartolini, Antonio Orca, deputati della Magnifica Citta/in segno di umilissimo/ossequio Uldarico Moro." GMV 65075, restaurirano: HRZ, Odsjek za papir i kožu, 2016. 


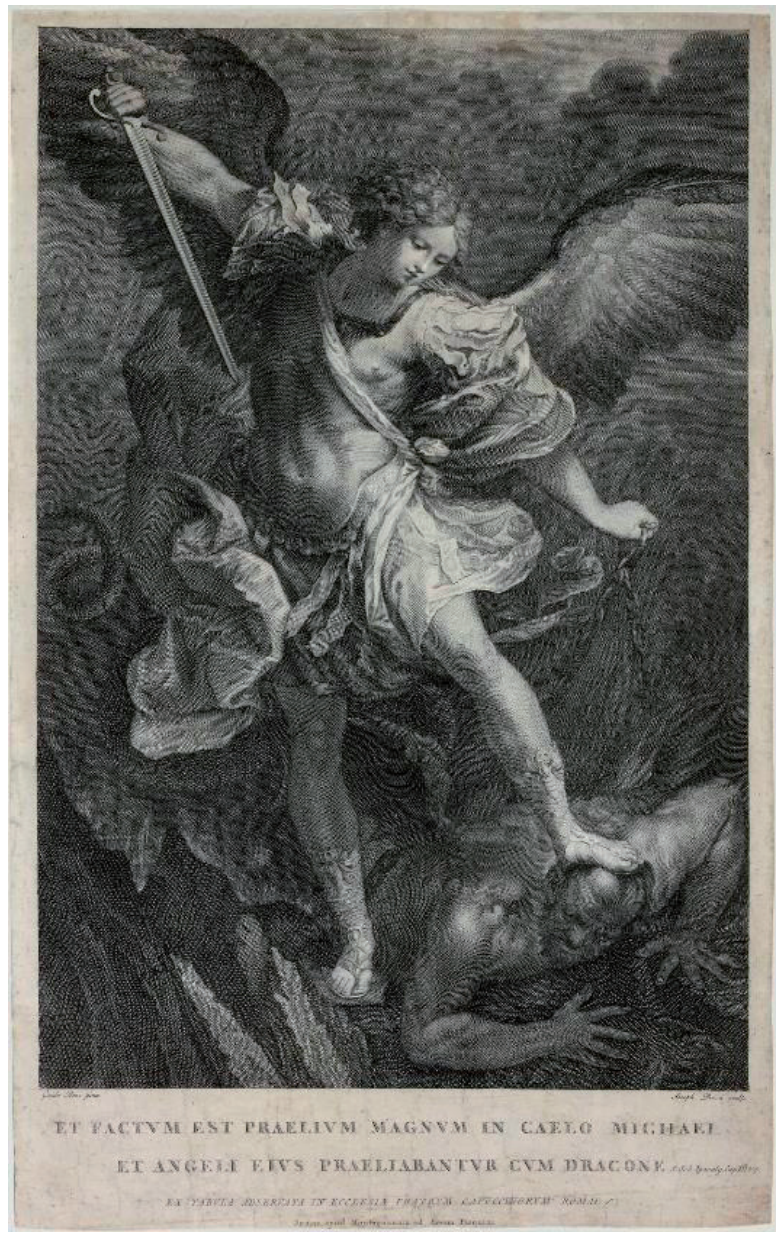

Slika 14. Arkanđeo Mihael, 18. stoljeće. Slikar: Guido Reni, rezač: Giuseppe Sforza Perini, bakropis; papir; 52,5 x 32,5 cm ${ }^{17}$

Od engleskih majstora grafike nezaobilazno je ime Jamesa Gillraya (1757. 1815.) koji se bavio izradom samostalnih grafičkih listova kao i karikatura za novine. Upravo jedan takav grafički list s karikaturalnom tematikom nalazi se i u zbirci pod nazivom Više svinja nego sisa iz 1806. godine. Služio se tehnikom jetkanja.

17 Sign. d.I. “Guido Reni pinx.“; d.d. „Joseph Perini sculp.“ Natpis ispod slike: “Et factum est praelium magnum in caelo michael et angeli eius praelibantur cum dracone", GMV 65444. Restaurirano: HRZ, Odsjek za papir i kožu, 2016. 
Zanimljiva je činjenica da su u zbirci zastupljena izuzetno rijetka i vrijedna djela japanskih grafičara Eishija Hosoda (1756.-1829.) Gejša s pratnjom i Gejša s vazom, Kitagawe Utamara (1753. - 1806.) Ljubavnici, Rezanje papira, Kosmaia Yoshinobe (18. stoljeće) Ispijanje čaja, Suzukija Harunobe (1725. - 1770.) Prizor iz Fuzokuge, pristigla u muzej iz dvorca u Jalkovcu (nedaleko od Varaždina) od obitelji Leitner.

Grafički listovi i mape Zbirke slika, skulptura, grafika i crteža čine veliko bogatstvo muzeja i fundusa, zahvaljujući prije svega velikom broju europskih vodećih imena u povijesti grafičke umjetnosti, što se očituje kroz ovaj kratak pregled koji donosi različitost autora, radionica, tiskara i izdavačkih kuća. Unazad desetak godina, istraživanja na grafikama postaju sve intenzivnija, jedan od razloga je suradnja s HRZ-om na njihovoj restauraciji, a s time i sve češća prezentacija javnosti kroz izložbe i publikacije.

\section{DIO}

Tijekom višegodišnje uspješne suradnje Odsjeka za papir i kožu i Gradskog muzeja Varaždin stručnjaci Odsjeka za papir i kožu imali su priliku detaljno upoznati i sudjelovati u procesu obnove velikog broja značajnih umjetničkih djela od kojih vrijedi izdvojiti izuzetno zanimljive i rijetke japanske ukiyo-e drvoreze te niz grafika značajnih europskih grafičara od 17. do 20. stoljeća.

"Ukiyo" je budistički termin kojim se označavao pojam zanemarivanja materijalnog svijeta, a koji se kasnije, tijekom 15. stoljeća koristi u pjesništvu i prozi kao izraz ideje života kao prolaznog sna. Riječ ukiyo-e počela se nadalje koristiti u opisivanju hedonističke životne filozofije, naročito u feudalnim danima Edo perioda od 1600. do 1868. godine, a označavala je svijet užitaka ili "svijet koji je plutao izvan svakodnevnih briga običnih ljudi". ${ }^{18}$

Dva japanska ukiyo-e drvoreza „Gejša s pratnjom“ i „Gejša s vazom“ iz Zbirke slika, skulptura, grafika i crteža Gradskog muzeja Varaždin, djelo su znamenitog japanskog majstora Eishia Hosode rođenog 1756. godine u obitelji samuraja Hosoda. Živio je u Edu (današnji Tokyo), gdje je počeo studirati slikarstvo u Kano školi, a zatim ukyo-e kod majstora Bunryusaia. Koristeći stil Kano, Eishi je postao dvorski slikar i visoki sudski dužnosnik. Kasnije napušta poziv dvorskog slikara i posvećuje se izradi ukiyo-e drvoreza inspiriran prizorima ženske ljepote i ljepotama prirode majstora Kitagawe Utamara (1753.-1806.). Drvorezi koji su otisnuti na izrazito tankom japanskom papiru, zatečeni su u izrazito lošem stanju sa

18 Tonči Tadić, Hrvatsko-japansko kulturno i gospodarsko društvo, iz teksta kataloga „Ukiyoe/slike plutajućeg svijeta“, Muzej starog grada - Hvar, Galerija Juraj Plančić, kolovoz-listopad 2008, str. 1. 
raznovrsnim oštećenjima (sl. 1, 2). Površinska nečistoća, neodgovarajući način njihova opremanja u prošlosti, izlaganje svjetlosti, neodgovarajućoj temperaturi i vlazi potenciralo je različite vrste oštećenja. Od mehaničkih oštećenja zatečene su višestruke poderotine, mnogobrojni blaži i intenzivniji pregibi te nedostajući dijelovi. Oba drvoreza su bila zalijepljena na karton, čime su izrazito tanki papirni nositelji dodatno degradirali zbog izlaganja podlozi kisele $\mathrm{pH}$ vrijednosti. Iz navedenih razloga proizašla su oštećenja u vidu krtosti, potamnjelih papirnih nositelja te foxinga. ${ }^{19}$ Na primjeru drvoreza „Gejša s pratnjom“ papirni nositelj je bio izrazito mehanički oštećen u obliku višestrukih poderotina (sl. 3) koje su dovele do dezintegracije cjeline prizora i samog papirnog nositelja koji se na pojedinim pozicijama osipavao. Od većih mehaničkih oštećenja zatečen je jedan veći nedostajući fragment u donjem desnom uglu, zatim je utvrđeno i oštećenje u vidu rezanja originalnog formata, dok je papirni nositelj bio toliko krt da se na pojedinim mjestima na dodir gotovo pretvarao u prah. Na drvorezu „Gejša s vazom“ sitnije su poderotine bile prisutne duž margina papirnog nositelja, nedostajući dijelovi zatečeni su na gornjem dijelu desne margine, na lijevom dijelu donje margine te na prikazu ruke i pregiba kimona gejše u području ramena, dok su sitni pregibi vidljivi po čitavom licu, a na pozicijama nedostajućih dijelova zatečene su tradicionalne zakrpe koje se izrađuju od zlatnih listića (sl. 4). Osim navedenih japanskih drvoreza radovi su izvedeni na litografijama, bakrorezima i bakropisima datiranim od 17. do 20. st. europske provenijencije, točnije njemačkih autora kao što su Franziska Redelsheimer i Max Pollak te flamanskog majstora Georga Hoefnagela i poznatog nizozemskog majstora Romeyna de Hooghea. Na djelima navedenih autora zatečena su oštećenja u obliku površinske nečistoće, požutjelog i potamnjelog papirnog nositelja, mrlja različitog porijekla te mehaničkih oštećenja. Georg Hoefnagel (1542.-1601.), poznati je flamanski slikar, minijaturist, iluminator i grafičar, posebno se istakao u izradi veduta i mapa za knjige te topografskih karata koje su ga proslavile. Veduta Kostajnice „Castanowiz Croatia Propugnaculum “iz iste Zbirke izvedena je u tehnici ručno koloriranog bakroreza (sl. 5). Objavljena je u „Civitates orbis terrarum“ autora Georga Brauna i Franz Hogenberga iz Kölna, u vlastitoj nakladi u šest edicija u razdoblju od 1572 . do 1617. godine. lako je Hoefnagel naveden kao autor ručno koloriranog bakroreza "Castanowiz Croatia Propugnaculum", radi se o naknadnom ponovnom otiskivanju, odnosno pretisku izrađenom 1617. godine. Djelo je pretrpjelo niz mehaničkih oštećenja od poderotina duž svih margina papirnog nositelja do pregiba

19 „Foxing“ sitne žuto-smeđe mrlje vidljive na papiru u pravilnom razmaku za koje se pretpostavlja da su čestice metala koje su oksidirale i proširile se unutar strukture papira. 
i nedostajućih dijelova te nekoliko blažih mrlja. Georg Hoefnagel je uz nekoliko drugih majstora gravera sudjelovao i u izradi prvog poznatog modernog atlasa „Theatrum Orbis Terrarum“ “iz 1570. godine. Čuveni nizozemski bakropisac, crtač, slikar, kipar i važan predstavnik kasnog nizozemskog baroka Romeyn de Hooghe, (1645.-1708.), bio je i kroničar razdoblja u kojem je živio, dokumentirao je niz važnih prikaza povijesnih događaja svog doba. De Hoogheov bakropis pod nazivom „Belgrado met syn slot en voor-steeden stormenderhand verovert door de keyserlyke machtenden 6 sept: 1688. “ uz mnoštvo detalja prikazuje oslobađanje Beograda od osmanske vlasti i to pod vodstvom bavarskog kneza Maksimilijana II., jednog od najambicioznijih europskih vladara tog vremena. Navedeni bakropis s poleđine je bio podlijepljen na tanak papir, a na pozicijama poderotina bile su aplicirane neodgovarajuće zakrpe od industrijskog papira glatke površine. Uz to, zatečena su i mehanička oštećenja u obliku poderotina duž svih margina papirnog nositelja, manji pregibi i nedostajući dijelovi. Uz gornju i lijevu marginu papirnog nositelja zatečene su i nepravilne mrlje bijelog obojenja (sl. 6). Jedna od rijetkih žena grafičarki, Franziska Redelsheimer istaknula se kao vrsni bakropisac i litograf. Djelovala je u Frankfurtu na Majni, gdje je i studirala grafiku u klasi gravera Bernarda Mannfelda na umjetničkom insititutu Städel od 1895. do 1902. godine. Njezina omiljena tema bile su gradske vedute i pejzaži, pogotovo Frankfurt i okolica kojeg nalazimo i na litografiji iz varaždinskog muzeja „Die Gerbermühle bey Frankfurt am Main“, s prikazom vedute štavionice i mlina u okolici grada.

Na svim grafikama navedenih autora zatečena su mehanička oštećenja kao i oštećenja od mrlja različitog porijekla. Posebno intenzivna i tvrdokorna smeđa vodena mrlja prekrivala je poziciju ispod gornjeg desnog ugla na litografiji „Die Gerbermühle bey Frankfurt am Main“, Franziske Redelsheimer, iz 1903. godine. Litografija je bila izrazito mehanički oštećena na način da je poderana duž nepravilne dijagonalne osi na dva dijela, dok je na licu, na neodgovarajući način učvršćena samoljepivim žutim trakama koje su uzrokovale nepovratna oštećenja površine originalnog otisnutog sloja i same strukture papirnog nositelja. Nadalje, od mehaničkih oštećenja na papirnom nositelju litografije zatečene su i poderotine te nedostajući dijelovi u gornjem desnom te donjem lijevom uglu i duž donje margine papirnog nositelja, dok je izrazito tvrdokorna smeđe obojana velika mrlja (sl. 7). Jedan od najznačajnijih austrijskih grafičara 1920-tih godina Max Pollak (1886.-1970.), vješto je izrađivao vedute, portrete, studije figura, aktove i prikaze životinja i to najčešće u tehnici suhe igle i bakropisa. Rođen je u Pragu, no kasnije seli u Beč, gdje studira slikarstvo i grafiku u klasi Williama Ungera i Ferdinanda Schmutzera. Bio je i nositelj prestižne nagrade Prix de Rome za svoja 
grafička djela, kasnije je emigrirao u SAD, gdje je nastavio daljnju karijeru. Danas su njegova djela izložena u najeminentnijim muzejima SAD-a kao što su Metropolitam Museum of Art i New York Public Library u New Yorku te British Museum u Londonu. Pollakova grafika „Universitätsplatz“ datirana je u 1864. godinu, izvedena je u tehnici bakropisa i suhe igle, a prikazuje sveučilišni trg u Beču sa zgradom Akademije znanosti i Sveučilišnom crkvom. Zadobila je niz manjih mehaničkih oštećenja duž margina papirnog nositelja.

Konzervatorsko-restauratorski radovima prethodila je izrada opisne dokumentacije zatečenog stanja kao i fotografsko dokumentiranje istog. Postupak suhog čišćenja papirnih nositelja djela provodio se pažljivo zbog višestrukih mehaničkih oštećenja te izrazito tankog japanskih papira na kojima su otisnuti ukiyo-e drvorezi. U takvim okolnostima rabilo se restauratorsko brisaće sredstvo u prahu Document cleaning powder i ono u spužvastoj formi Akapad white sponge. Kako bi se stekao što detaljniji uvid u stabilnost papira, pomoću pH-metra je površinskom elektrodom izvedeno mjerenje $\mathrm{pH}$ vrijednosti papirnih nositelja. Na drvorezu „Gejša s vazom“ pH vrijednosti su varirale od 4.66 do 6.21, a na drvorezu „Gejša s pratnjom“ od 5.27 do 5.95, što ukazuje na blažu kiselost. S obzirom na to da su zatečene kisele kartonske podloge dugoročno štetne za umjetnine, uklonjene su s poleđina dvaju japanskih drvoreza. Postupak je izveden pomoću skalpela i ovlaženog tampona postupnim tanjenjem/raslojavanjem kartona te dodatno aktivacijom nakupina ljepila pomoću otapala, u svrhu lakšeg odvajanja poleđine drvoreza s kartonske podloge. Nakon testiranja postojanosti pigmenata boja pokazalo se da su boje stabilne u kontaktu s destiliranom vodom i etanolom te je stoga bilo moguće provesti mokro čišćenje uranjanjem grafika u navedenu smjesu. Nakon mokrog čišćenja uslijedio je postupak neutralizacije papirnih nositelja u vodenoj otopini kalcijevog-hidroksida čime se uspostavlja alkalna rezerva ili pufer koji nadalje ima ulogu neutraliziranja kiselina koje se mogu razviti tijekom vremena. Konsolidacija zatečenih mehaničkih oštećenja kao i rekonstrukcija nedostajućih dijelova izvedena je pomoću određenih japanskih papira odgovarajućih gramatura i celuloznog ljepila. Odabrani japanski papir kojim su rekonstruirani nedostajući dijelovi dodatno je toniran kako bi se što bolje uklopio uz lokalni ton drvoreza. Mnogostruke poderotine dovele su i do dezintegracije cjelovitosti papirnog nositelja, što je ukazalo na potrebu ojačavanja čitave poleđine nositelja drvoreza. Ojačavanje poleđine izvedeno je pomoću celuloznog ljepila i japanskog papira u manjim četvrtastim formatima koji su podljepljivani na poleđinu tako da se svi neznatno preklapaju preko margina svakog, čime je postignuto razbijanje napetosti koju često izaziva dodavanje novog sloja na originalni papirni nositelj. Nakon dovršenih zahvata konsolidacije poderotina i izrade 
nadopuna nedostajućih dijelova, drvorezi su ovlaženi unutar komore za ovlaživanje i podvrgnuti postupku ravnanja polaganjem između slojeva filca i bugačica pod ravnomjernim pritiskom. Retušem koji je slijedo u završnom procesu radova površinska oštećenja su usklađena u cjelinu, a retuš je primijenjen minimalno kako bi se isprekidane konturne linije drvoreza upotpunile u cjelinu i to minimalnom intervencijom crnom pastelom.

Ovisno o specifičnom zatečenom stanju papirnih nositelja grafika i postojanosti izvedbene tehnike, primjenjivale su se odgovarajuće metode konzervatorsko-restauratorskih postupaka. U početnoj fazi radova pristupilo se izradi opisa stanja svake pojedine grafike, mjerenje dimenzija i dokumentiranje vodenih znakova ukoliko su zatečeni na papirnom nositelju. Proces rada na grafikama započeo je suhim čišćenjem, odnosno otprašivanjem lica i poleđine specijalnim kistom za uklanjanje površinske nečistoće, po potrebi se koristila i restauratorska spužva za čišćenje tvrdokornije površinske nečistoće te pjenasta gumica dok se kod osjetljivih i najoštećenijih djela koristilo brisaće sredstvo u prahu. Površinskom elektrodom $\mathrm{pH}$-metra izmjerene su $\mathrm{pH}$ vrijednosti papirnih nositelja grafika kako bi se stekao bolji uvid u njihova stanja i stabilnost. Vrijednosti su se kretale od 5.0 do 6.23, što upućuje na blažu kiselost. S poleđine bakropisa „Belgrado met syn slot en voor-steeden stormenderhand verovert door de keyserlyke machtenden 6 sept: 1688.", čuvenog nizozemskog majstora Romeyna de Hooghea, uklonjena je zatečena podloga u obliku tanjeg papira, kao i neodgovarajuće zakrpe od industrijskog papira i to postupkom uranjanja u smjesu vode i etanola. Na litografiji „Die Gerbermühle bey Frankfurt am Main“ je nakon suhog čišćenja izvedeno uklanjanje fragmenata samoljepljivih traka zatečenih na licu odgovarajućim otapalom. Potom je tretirana tvrdokorna smeđa mrlja koja nije u potpunosti uklonjena s obzirom na oslabljeni papirni nositelj jer djelovanje određenih otapala može izazvati narušavanje stabilnosti papira koji je već pretrpio značajnu degradaciju. Podljepljivanje litografije u cjelinu izvedeno je celuloznim ljepilom i japanskim papirom veće gramature s obzirom na to da je bila poderana duž nepravilne dijagonalne osi i to na dva dijela. Neutralizacija papirnih nositelja kod stabilnih grafičkih tehnika izvedena je klasičnim postupkom otopinom destilirane vode i kalcijevim-hidroksidom. Konsolidacija poderotina i izrada nadopuna nedostajućih dijelova izvedena je japanskim papirom odgovarajuće gramature i celuloznim ljepilom, zatim su grafike ovlažene unutar komore za ovlaživanje i podvrgnute postupku ravnanja između slojeva filca i bugačica pod ravnomjernim pritiskom hidraulične preše. Po završetku radova, restaurirane grafike su zaštićene unutar opreme za pohranu od muzejskog pH neutralnog kartona koja omogućuje zaštitu pri čuvanju i rukovanju (sl. 8-12). 


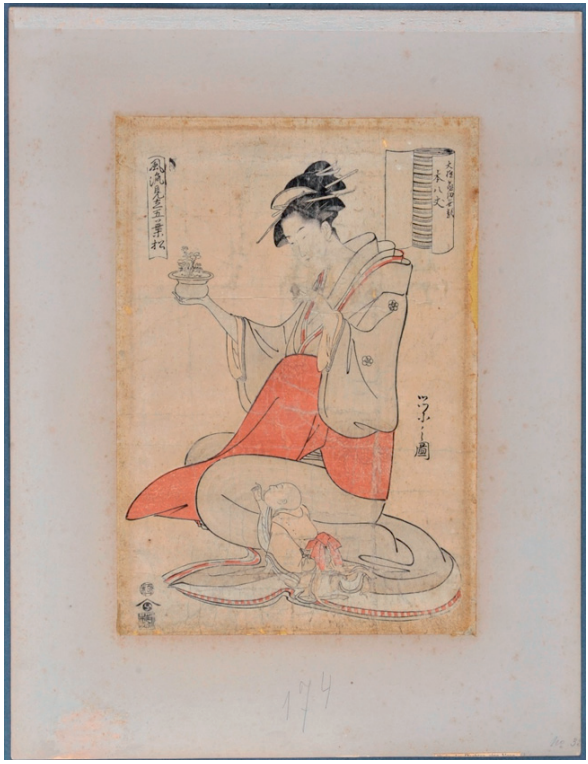

Slika 1. Gejša s vazom, Eishi Hosoda, zatečeno stanje drvoreza podlijepljenog na deblji industrijski papir

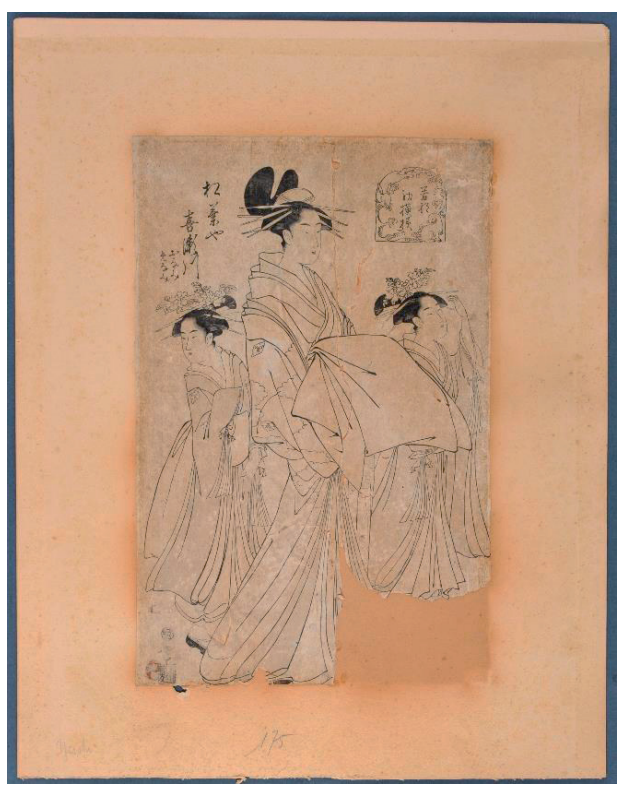

Slika 2. Gejša s pratnjom, Eishi Hosoda, zatečeno stanje drvoreza podlijepljenog na karton 


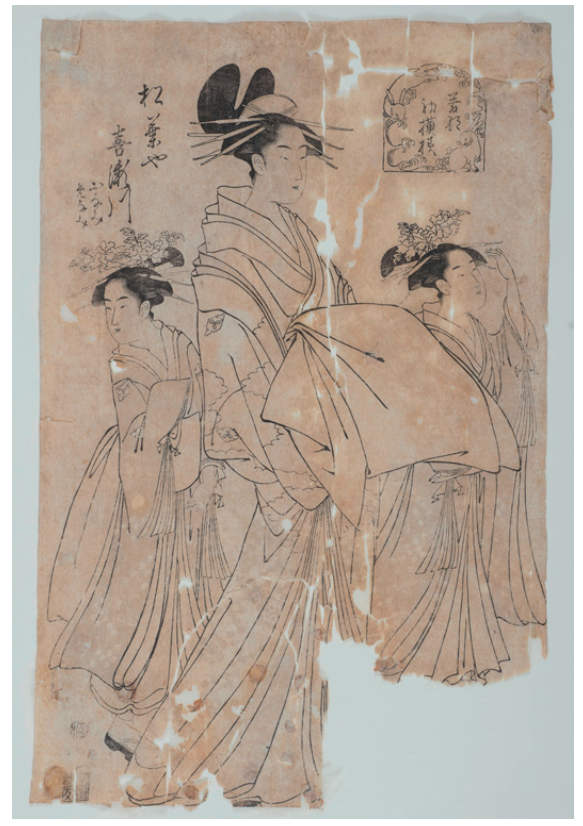

Slika 3. Gejša s pratnjom, Eishi Hosoda, zatečena višestruka mehanička oštećenja drvoreza vidljiva nakon odvajanja s kartona

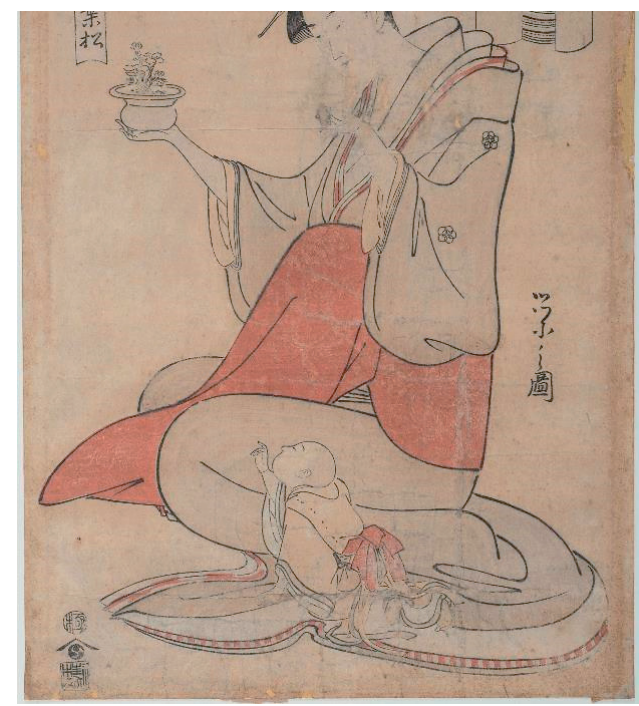

Slika 4. Oštećenja u obliku sitnih pregiba po čitavom drvorezu Gejša s vazom, na pozicijama nedostajućih dijelova zatečene su tradicionalne zakrpe koje se izrađuju od zlatnih listića 
ELIZABETA IGREC, DANIELA RATKAJEC: Izabrani primjeri grafika iz Zbirki galerije starih i novih majstora ...

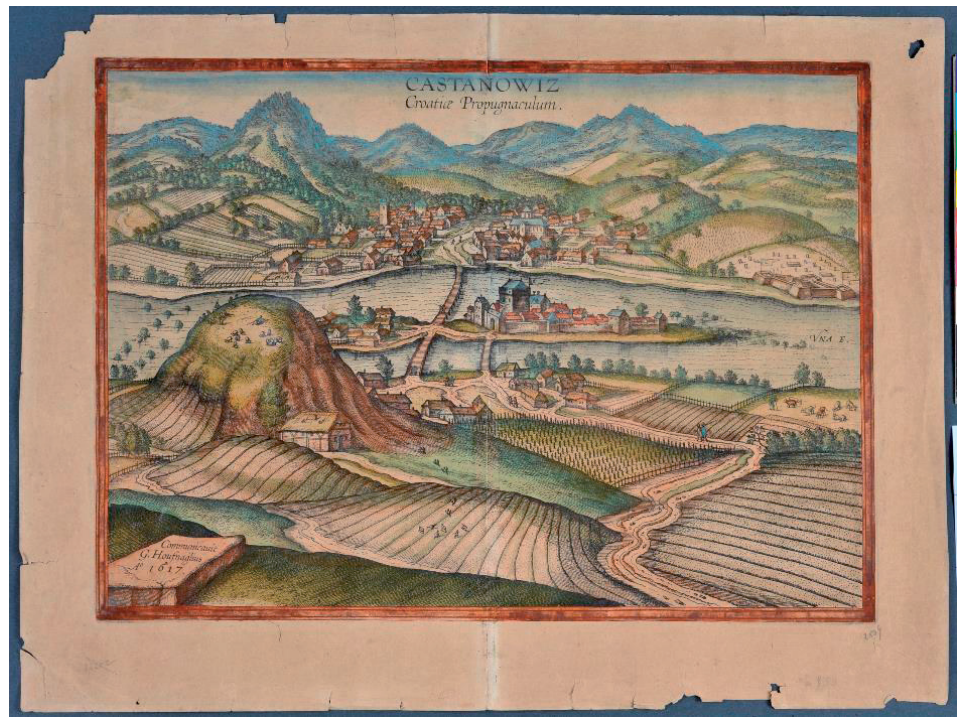

Slika 5. Veduta Kostajnice Castanowiz Croatia Propugnaculum, zatečeno stanje bakropisa s mehaničkim oštećenjima, pretisak prema originalu Georga Hoefnagela

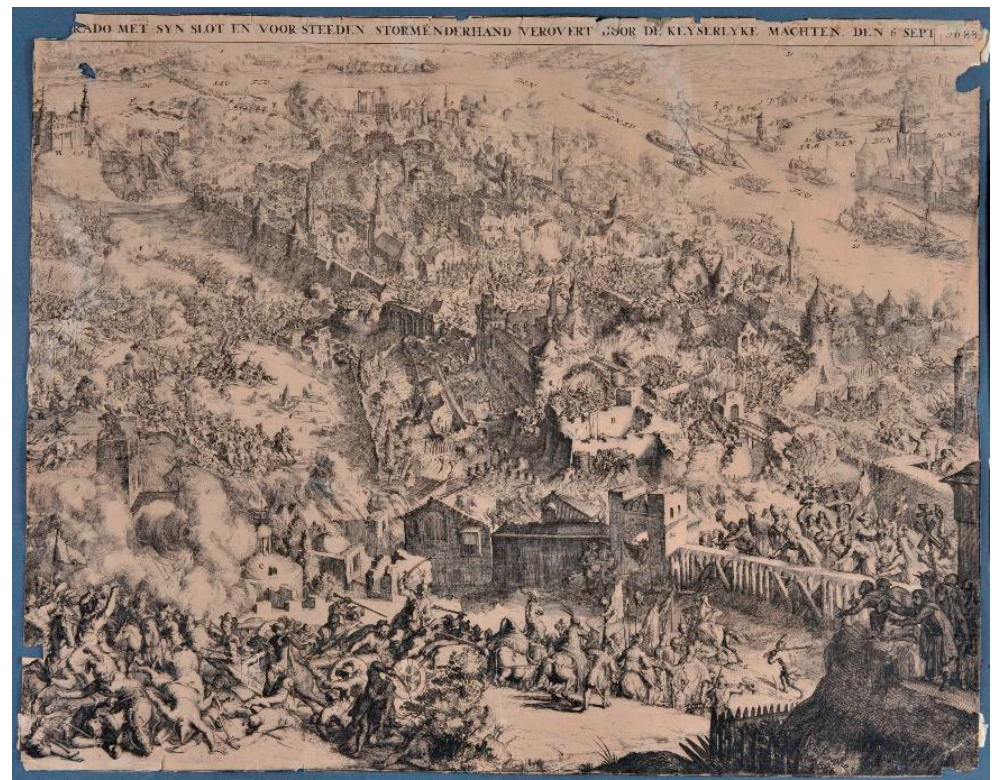

Slika 6. Belgrado met syn slot en voor-steeden stormenderhand verovert door de keyserlyke machtenden 6 sept: 1688., Romeyn de Hooghe, stanje bakropisa prije radova s vidljivim višestrukim oštećenjima 


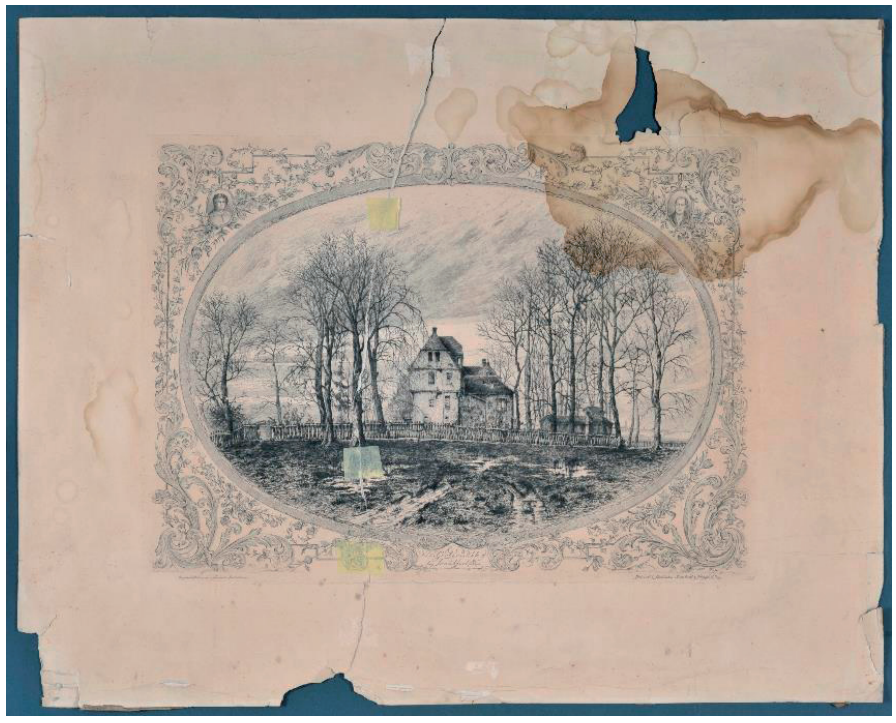

Slika 7. Die Gerbermühle bey Frankfurt am Main, Franziska Redelsheimer, stanje litografije prije radova, sa izrazitim mehaničkim oštećenjima i poderotinom, odvojenim dijelovima, sa samoljepivom trakom na licu grafike te tvrdokornom mrljom u gornjem desnom uglu

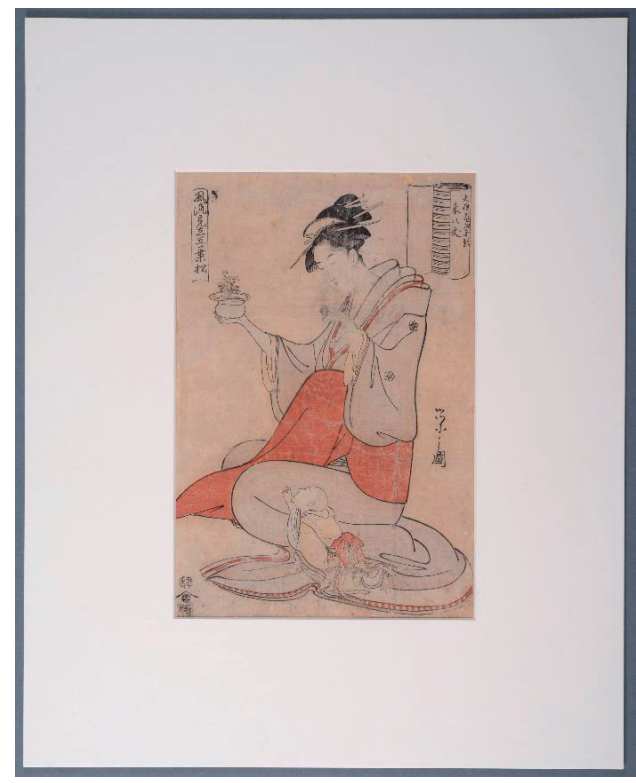

Slika 8. Gejša s vazom, stanje drvoreza nakon radova unutar opreme za pohranu 
ELIZABETA IGREC, DANIELA RATKAJEC: Izabrani primjeri grafika iz Zbirki galerije starih i novih majstora ...

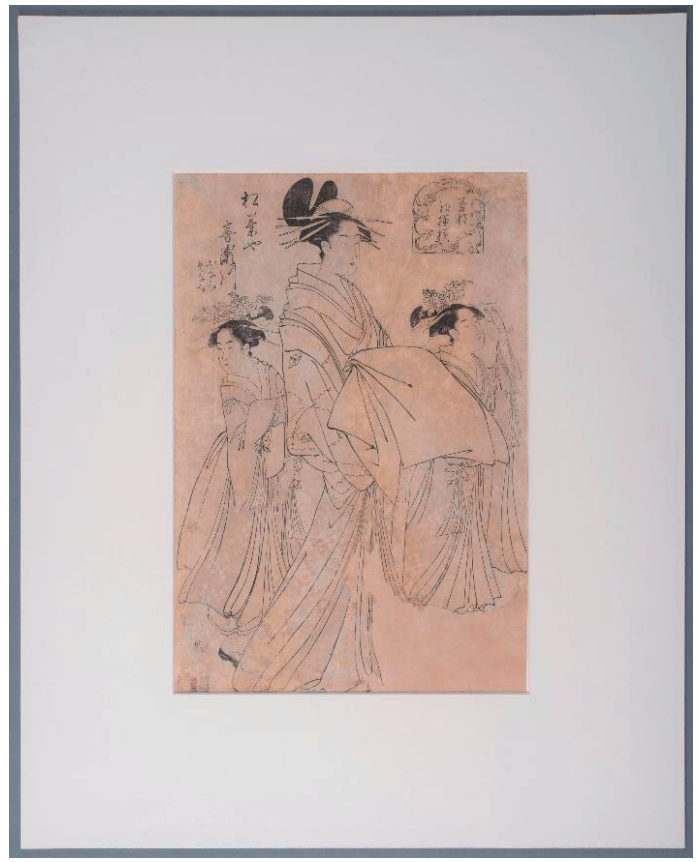

Slika 9. Gejša s pratnjom, stanje drvoreza nakon radova unutar opreme za pohranu

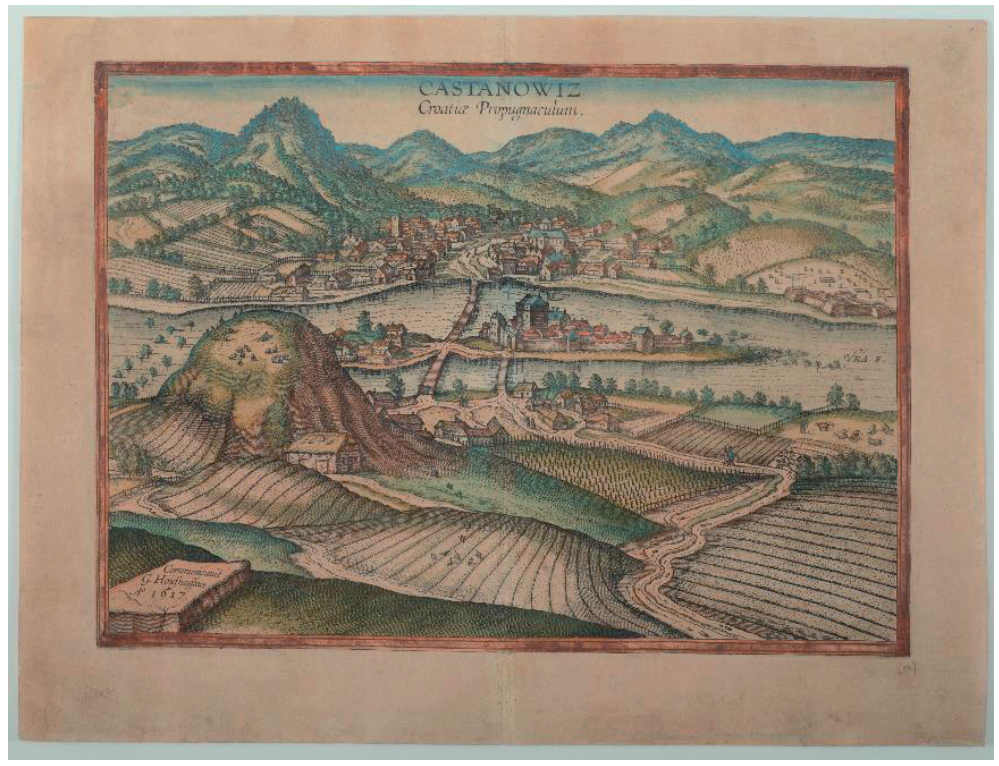

Slika 10. Castanowiz Croatia Propugnaculum, stanje bakropisa nakon radova 
Radovi Zavoda za znanstveni rad HAZU Varaždin; br. 30, 2019, str. 211-240

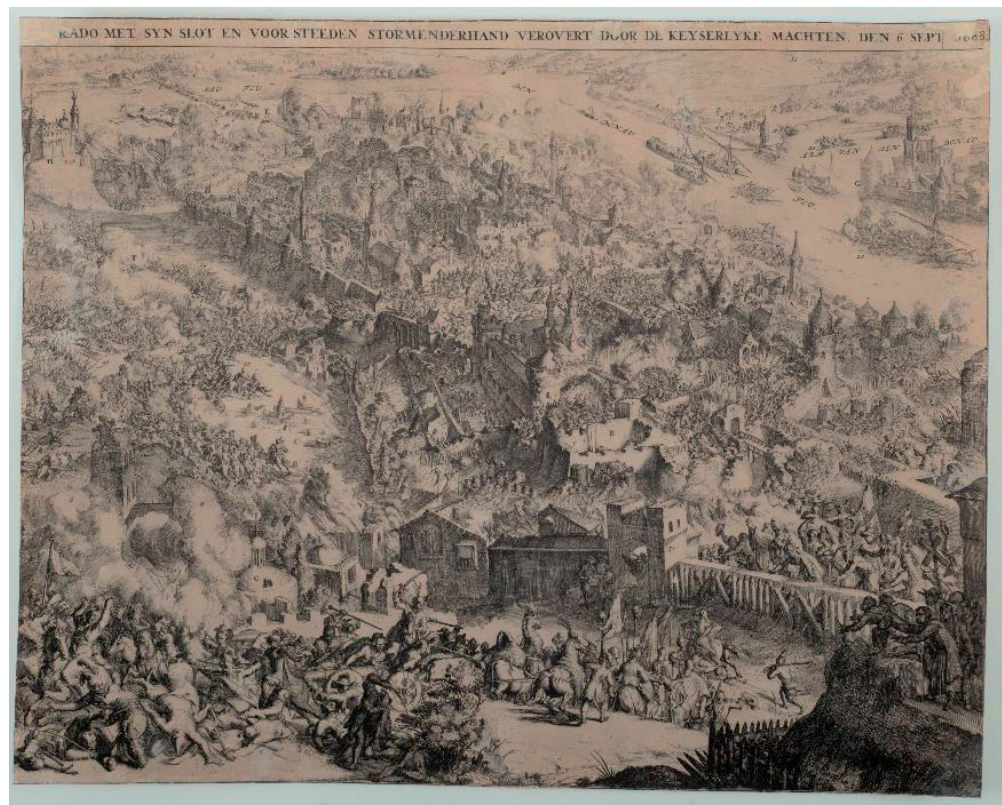

Slika 11. Belgrado met syn slot en voor-steeden stormenderhand verovert door de keyserlyke machtenden 6 sept: 1688, stanje bakropisa nakon radova

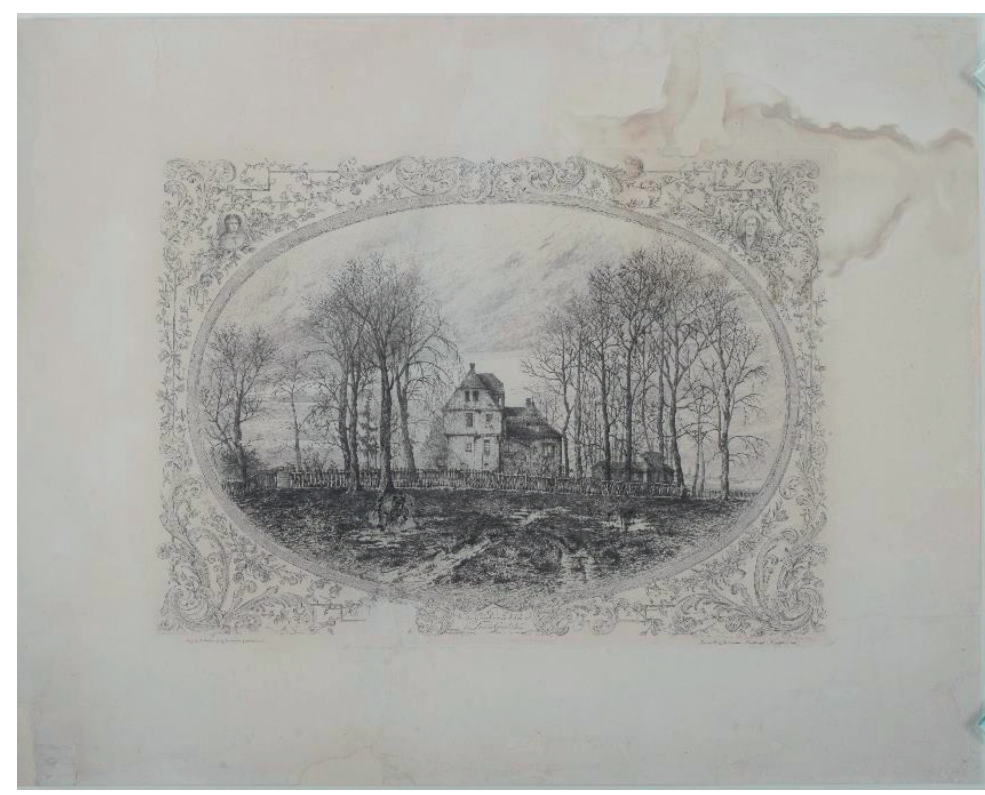

Slika 12. Die Gerbermühle bey Frankfurt am Main, stanje litografije nakon radova 


\section{LITERATURA}

Katalog:

1/ Blago Japana i Kine, Gradski muzej Varaždin, tekst kataloga, Varaždin, 2012.

2/ Mirjana DUČAKIJEVIĆ, Ljepote grafičke umjetnosti, Gradski muzej Varaždin, tekst kataloga, Varaždin, 2011.

3/ Tonči TADIĆ, (Hrvatsko-japansko kulturno i gospodarsko društvo), tekst kataloga „Ukiyoe/slike plutajućeg svijeta“, Galerija Juraj Plančić, Muzej starog grada - Hvar, kolovoz-listopad 2008., str. 1.

4/ Varaždin pod krunom Habsburgovaca, Gradski muzej Varaždin, tekst kataloga, Varaždin, 2015.

Popis korištenih bibliografskih jedinica:

1/ J. HILLER, „Japanese Masters of the Colour Print /A great Heritage of Oriental Art", Phaidon Press, London, 1954. second ed.: Kabinet grafike HAZU.

2/ Đevad HOZO, „Umjetnost multiorginala: kultura grafičkog lista“, Mostar, Prva književna komuna, 1988.

3/ Frane PARO, „Grafika, marginalije o crno-bijelom“, Mladost, Zagreb, 1991.

4/ Carl SCHRAUBSTADTER, „Care and repair of Japanese prints“, Asian Conservation Laboratory, New York, c 1978.

5/ Ad STIJNMAN, „Engraving and etching 1400-2000“, Archetype Publications Ltd., London, 2012.

6/ Ulrich THIEME i Felix BECKER, Allgemeines Lexicon der Bildenden Künstler von der Antike bis zur Gegenwart, Dritter Band, Bassano - Bickham, Leipzig, E. A. Seemann Verlag, 1992 (svezak 3, 5,13,15, 25, 29, 33, 35).

Web:

1/ Michael BRYAN, „Dictionary of painters and engravers“,London,1886., dostupno na https://archive.org/stream/cu31924092716962\#page/n375/ mode/1up/search/de+Bruyn, 28. 1. 2019.

2/ http://www.ndl.go.jp/landmarks/e/artists/hosoda-eishi/, pristupljeno, 4. 1. 2019.

3/ John FIORILLO, „Viewing Japanese Prints“, 1999., dostupno na www.viewingjapaneseprints.net 4. 1. 2019.

4/ Hans Olof JOHANSSON, "Signatures of Ukiyo-e Artists" ,Kanji characters with examples, 2000.- 2003., dostupno na www.ukiyo-e.se, 4. 1. 2019. 
5/ Julian PEÑA, „The Historical Impression of Ukiyo-E: How It Transformed the Floating World, Impacted the Western Civilization, and Influenced Modern Society", dostupno na www.wordpress.com, 4.1.2019.

6/ J. STRUTT, 'Biographical dictionary of all the engravers', London: printed by J. Davis, for Robert Faulder, 1785-86. 2v, dostupno na https://archive.org/ details/biographicaldict00stru, 4. 1. 2019.

7/ www.roningallery.com/artists/eishi, pristupljeno, 4. 1. 2019.

\section{SAŽETAK}

\section{IZABRANI PRIMJERI GRAFIKA IZ ZBIRKI GALERIJE STARIH I NOVIH MAJSTORA GRADSKOG MUZEJA VARAŽDIN}

Suradnja Gradskog muzeja Varaždin i Odsjeka za papir i kožu Hrvatskog restauratorskog zavoda rezultirala je velikim brojem restauriranih grafika, koje su spašene od daljnjeg propadanja, a svakoj od njih ponovno je dana mogućnost dostojnog prezentiranja i izlaganja. Kontinuirano iz godine u godinu sustavnim planom na godišnjoj razini restaurira se otprilike deset grafika. Za Gradski muzej Varaždin to je izuzetno vrijedna i važna stavka. Članak (1. dio) donosi kratak pregled Zbirke slika, skulptura, grafika i crteža čiji značajan udio čine grafike, uz predstavljanje i opis najznačajnijih odabranih grafičkih listova koji čine temelj i bogatstvo grafičke umjetnosti koja se čuva u muzeju.

U okviru višegodišnje uspješne suradnje Odsjeka za papir i kožu HRZ-a i Gradskog muzeja Varaždin, restauriran je veliki broj značajnih umjetnina na papiru od kojih vrijedi istaknuti dva japanska drvoreza iz 18. stoljeća. Autor navedenih drvoreza je japanski majstor Eishi Hosoda (1756.-1829.). Drvorezi su izvedbeno i tematski primjeri tipičnog ukiyo-e stila. Zatečeni su u izrazito lošem stanju očuvanosti, s višestrukim oštećenjima, zalijepljeni na kartonsku podlogu kisele $\mathrm{pH}$ vrijednosti. Uz drvoreze ističu se grafike vrsnih europskih majstora grafičke umjetnosti od 17. do 20. stoljeća. Radi se o grafikama izvedenim u tehnikama litografije, bakroreza i bakropisa/suhe igle. Članak (2. dio) govori o zatečenim oštećenjima s naglaskom na konzervatorsko-restauratorske radove te kratkim osvrtom na navedena djela i njihove autore.

Ključne riječi: grafika; grafički list; umjetnine na papiru; konzervatorsko-restauratorski radovi; japanski „ukiyo-e“ drvorez. 


\section{SUMMARY}

\section{SELECTED EXAMPLES OF PRINTS FROM THE COLLECTIONS OF THE GALLERY OF OLD AND NEW MASTERS OF THE VARAŽDIN CITY MUSEUM}

The successful cooperation of the Varaždin City Museum and the Department of Paper and Leather of the Croatian Conservation Institute has resulted in a large number of restored prints rescued from further decay. Each of them can now be presented and shown as deserved. From year to year, approximately ten prints are restored annually according to a systematic plan. This is an extremely valuable and important cooperation for the Varaždin City Museum. The paper (Part 1) deals with a brief overview of the Collection of paintings, sculptures, prints and drawings the significant part of which are the prints. The presentation and the description of the most important selected prints that make up the basis of the highly valuable prints in the Museum are described.

Within the years of a successful cooperation between the Department for Paper and Leather and the Varaždin City Museum a large number of significant artworks on paper have been restored. Two Japanese woodblock prints from the 18th century are the highlights. The author of these woodblocks is the Japanese master Eishi Hosoda (1756-1829). The woodblocks have been produced in the typical Ukiyo art style. We found them in extremely poor condition, with multiple damages, glued to a cardboard base of acid $\mathrm{pH}$ value. The prints of the great European masters of graphic art from the 17th to the 20th centuries stand along with the said woodblocks. The prints are lithographs, engravings and etchings/ drypoints. The paper (Part 2) deals with the damages suffered, with emphasis on the conservation and restoration works, and a brief review of the works and their authors.

Key Words: artworks on paper; conservation and restoration works; Japanese Ukiyo E woodblock prints; lithography; engraving; etching/drypoint. 